\title{
The plasma proteins and their fractionation'.
}

By

\author{
John T. Edsall-Boston ${ }^{2}$.
}

With 5 Figures.

Table of Contents. Page

References ........................ 308

1. Introduction . . . . . . . . . . . . . . . . . . $3^{16}$

2. Some General Aspects of Fractionation by Means of Ethanol at Low Temperature and Low Ionic Strength . . . . . . . . . . . . . . . 319

3. Choice of Conditions in the Fractionation of Plasma . . . . . . . . . . 323

4. The Subfractionation of Fraction I: Fibrinogen and the Anti-Hemophilic Globulin .... . 327

5. Subfractionation of Fraction II + III . . . . . 328

6. Components of Fraction IV 4 . . . . . . . . . . . . . . . . . . . . . . 338

7. Properties and Crystallization of Serum Albumin. . . . . . 341

8. The Lipoproteins of Plasma

9. Ether Fractionation of Human Plasma. . . 347

10. Size and Shape of Molecules in Plasma Fractions ....... 348

11. Amino Acid Analysis of Plasma Fractions. . . 348

12. Conclusions . . . . . . . . . . . . . . . . . 351

\section{References.}

1. Adair, G. S., and M. E. AdaIR: A Protein of Low Density Prepared from Human Serum. J. of Physiol. 102, 17P (1943).

2. Alberty, R. A.: A Quantitative Study of Reversible Boundary Spreading in the Electrophoresis of Proteins. J. amer. chem. Soc. 70, 1675 (1948).

2a. Ale Xander, B., and G. LANDwerr: Evolution of a Prothrombin Conversion Accelerator in Stored Human Plasma and Prothrombin Fractions. Amer. J. Physiol. 159, 322 (1949).

3. Armstrong, S. H. jr., M. J. E. Budka and K. C. Morrison: Preparation and Properties of Serum and Plasma Proteins. XI. Quantitative Interpretation of Electrophoretic Schlieren Diagrams of Normal Human Plasma Proteins. J. amer. chen. Soc. 69, 416 (1947).

4. - - - and M. HAsson: Preparation and Properties of Serum and Plasma Proteins. XII. The Refractive Properties of the Proteins of Human Plasma and Certain Purified Fractions. J. amer. chem. Soc. 69, 1747 (1947).

1 This review represents an extended version of a lecture on this subject given by the author in several German universities during June and July, 1948, while he was a member of a medical mission to Germany sponsored by the Unitarian Service Committee.

Much of the material in this review has been already presented in Volume III of Advances in Protein Chemistry (Academic Press, Inc., New York, 1947), but the present article has been revised to take account of the more recent advances in this subject.

2 Department of Physical Chemistry, Harvard Medical School, Boston 15, Mas5achusetts. 
5. Barkan, G,: Eisenstudien. 3. Mitteilung. Die Verteilung des leicht abspaltbaren Eisens zwischen Blutkörperchen und Plasma und sein Verhalten unter experimentellen Bedingungen. Z, physiol. Chem. 171, 194 (1927).

6. - Uber Bestimmungsmethodik und Eigenschaften des „leicht abspaltbaren" Bluteisens. 6. Mitteilung in der Reihe der Eisenstudien. Z. physiol. Chem. 216, 1 (1933).

7. - u. O. Schales: Chemischer Aufbau und physiologische Bedeutung des ,leicht abspaltbaren" Bluteisens. 13. Mitteilung in der Reihe der Eisenstudien. Z. physiol. Chem. 248, 98 (1937).

8. Bennhold, H. V.: Utber die Vehikelfunktion der Serumeiweißkörper. Erg. inn. Med. 42, 273 (1932).

9. - E. Kylin, u. S. Rusznyak: Die Eiweißkörper des Blutplasmas, S. 470. Dresden u. Leipzig: Theodor Steinkopff 1938.

10. Bering, E. A. jr.: Chemical, Clinical, and Immunological Studies on the Products of Human Plasma Fractionation. XX. The Development of Fibrin Foam as a Hemostatic Agent and for Use in Conjunction with Human Thrombin. J. clin. Invest. 23, 586 (1944).

11. BJERRUM, N.: Die Konstitution der Ampholyte, besonders der Aminosäuren, und ihre Dissoziationskonstanten. Z. physik. Chem. 104, 147 (1923):

12. Blix, $G_{,}$A. Tiselius and H. Svensson: Lipids and Polysaccharides in Electrophoretically Separated Blood Serum Proteins. J. of biol. Chem. 137, 485 (1941).

13. BoyD, W. C.: A Nomogram for Acetate Buffers. J. amer. chem. Soc. 67, 1035 (1945).

14. - RH Blood Factors: An Orientation Review. Arch. of Path. 40, 114 (1945).

15a. Boyer, P. D., F. G. Lum, G. A. Ballov, J. M. LuCK and R. G. Rice: The Combination of Fatty Acids and Related Compounds with Serum Albumin. I. Stabilization Against Heat Denaturation. J. of biol Chem. 162, 181 (1946).

16b. Brand, E.: Amino Acid Composition of Simple Proteins. Ann. N. Y. Acad. Sci. 47, 187 (1946).

17. -, and J. T. Edsall: The Chemistry of the Proteins and Amino Acids. Ann. Rev. Biochem. 16; 223 (1947).

18. - B. Kasseli and L. J. Sarder: Chemical, Clinical, and Immunological Studies on the Products of Human Plasma Fractionation. III. Amino Acid Composition of Plasma Proteins. J. clin. Invest. 23, 437 (1944).

19. Bridgman, W: B.: The Peptic Digestion of Human $\gamma$-Globulin. J. amer. chem. Soc. 68, 857 (1946).

20. Cameron, J.W., and L.K. Diamond: Chemical, Clinical, and Immunological Studies on the Products of Human Plasma Fractionation. XXIX. Serum Albumin as a Diluent for Anti-Rh Typing Reagent. J. clin. Invest. 24, 793 (1945).

20a. CANN, J. R., R. A. BRown and J. G. KIRkwood: Fractionation of $\gamma$-Globulin by Electrophoresis-Convection. J. amer. chem. Soc. 71, 2687 (1949).

21. Cannon, P. R., E. M. Humphreys, R. W. Wissier and L. E. Frazier: Chemical, Clinical, and Immunological Studies on the Products of Human Plasma Fractionation. XXIII. The Effects of Feeding Possible Blood Substitutes on Serum Protein Regeneration and Weight Recovery in the Hypoproteinemic Rat. J. clin. Invest. 23, 601 (1944).

22. C.Artwright, G. E., and M. M. Wintrobe: Chemical, Clinical, and Immunological Studies on Products of Human Plasma Fractionation. XXXIX. The Anemia of Infection. Studies on the Iron-Binding Capacity of Serum. J. clin. Invest. 28, 86 (1949).

23. Chargatf, E.: Lipoproteins. Advances prot. Chem. 1, 1 (1944).

24. Christensen, L. R.: Streptococcal Fibrinolysis: A Proteolytic Reaction Due to a Serum Enzyme Activated by Streptococcal Fibrinolysin. J. gen. Physiol. 28, 363 (1945).

25. - The Activation of Plasminogen by Chloroform. J. gen. Physiol. 30, 149 (1946). 
26. Christensen, L. R.: and C. M. MacLeod: A Proteolytic Enzyme of Serum: Characterization, Activation, and Reaction with Inhibitions. J. gen. Physiol. 28. 559 (1945).

27. Corn, E. J.: The Activity Coefficients of the Ions in Certain Phosphate Solutions. A Contribution to the Theory of Buffer Action. J. amer. chem. Soc. 49, 173 (1927).

28. - Blood and Blood Derivatives. Amer. Scientist 33, 61 (1945).

29. - Blood, Blood Derivatives, and Blood Substitutes. Proc. amer. phil. Soc. 88, 159 (1944)

30. - Blood Proteins and Their Therapeutic Value. Science (Lancaster, Pa.) 101 , 51 (1945).

31. - Chemical, Physiological, and Immunological Properties and Clinical Uses of Blood Derivatives. Experientia 3, 125 (1947).

32. - The History of Plasma Fractionation, Bd. I, Kap. XXVIII, S. 364. Advances in Military Medicine. Boston: Little, Brown \& Co. 1948.

33. - Personal communication.

34. - The Properties and Functions of the Plasma Proteins, with a Consideration of the Methods for Their Separation and Purification. Chem. Rev. 28, 395 (1941).

35. - and J. T. Ensall: Proteins, Amino Acids, and Peptides as Ions and Dipolar Ions. New York: Reinhold Publishing Corp. American Chemical Society Monograph, No 90. 1943.

35a. - F. R. N. Gurd, D. M. Surgenor, B. A. Barnes, R. K. Brown, G. DerouauX, J. M. Gillespie, F.W. Kahnt, W. F. Lever, C. H. Liv, D. Mittelman, R. F. Mouton, K. Schmid and E. URoma: Quantitative Procedures for the Separation of Protein Components. I, A System for the Separation of the Plasma Protein Components of Human Blood. J. amer. chem. Soc. 72, 474 (1950).

36. - W. L. Hughes jr. and J.H. Weare: Preparation and Properties of Serum and Plasma Proteins. XIII. Crystallization of Serum Albumins from EthanolWater Mixtures. J. amer. chem. Soc. 69, 1753 (1947).

37. -- J. A. Luetscher jr., J. L. OnCley, S. H. Armstrong jr. and B. D. Davis: Preparation and Properties of Serum and Plasma Proteins. III. Size and Charge of Proteins Separating upon Equilibration across Membranes with Ethanol-Water Mixtures of Controlled $\mathrm{pH}$, Ionic Strength, and Temperature. J. amer. chem. Soc. 62, 3396 (1940).

38. - J.L. Oncley, L.E.Strong, W.L.Hughes jr. and S.H. Armstrong jr.: Che" mical, Clinical, and Immunological Studies on the Products of Human Plasma Fractionation. I. The Characterization of the Protein Fractions of Human Plasma. J. clin. Invest. 23, 417 (1944).

39. - L. E. Strong, W. L. Hughes jr, D. J. Mulgord, J. N. Ashworth, M. Mel and H. L. TAYLoR: Preparation and Properties of Serum and Plasma Proteins. IV. A System for the Separation into Fractions of the Protein and Lipoprotein Components of Biological Tissues and Fluids. J. amer. chem. Soc. 68, 459 (1946).

40. Davis, B. D.: The Binding of Sulfonamide Drugs by Plasma Proteins. A Factor of Determining Distribution of Drugs in Body. J. clin. Invest. 22, 753 (1943).

41. DeBye, P., u. E. Hü CKEL: Zur Theorie der Elektrolyte. I. Gefrierpunktserniedrigung und verwandte Erscheinungen. Physik, Z. 24, 185 (1923).

42. De Gowin, E. L.: Chemical, Clinical, and Immunological Studies on the Products of Human Plasma Fractionation. XIV. Appraisal of Isohemagglutinin Activity. J. clin. Invest. 23, 554 (1944).

43. Delezenne, C., et E. Pozerski: Action Proteolytique du Sérum Sanguin Préalablement Traité par le Chloroforme. C. r. Soc. Biol. Paris 55, 690 (1903). Action Kinasique du Sérum Sanguin Préalablement Traité par le Chloroforme. C. r. Soc. Biol. Paris 55, 693 (1903).

44. Deutsch, H. F., R. A. Aleerty and L. J. Gosting: Biophysical Studies of Blood Plasma Proteins. IV. Separation and Purification of a New Globulin from Normal Human Plasma. J. of biol. Chem. 165, 21 (1946). 
45. Deutsch, H. F.: and M. B. Goodroe: An Electrophoretic Survey of Various Animal Plasmas. J. of biol. Chem. 161, 1 (1945).

46. - L. J. Gosting, R. A. Alberty and J. W. Williams: Biophysical Studies of Blood Plasma Proteins. III. Recovery of $\gamma$-Globulin from Human Blood Protein Mixtures. J. of biol. Chem. 164, 109 (1946).

47. - M. L. PetermanN and J. W. Williams: Biophysical Studies of Blood Plasma Proteins. II. The Pepsi Digestion and Recovery of Human $\gamma$-Globulin. J. of biol. Chem. 164, 93 (1946).

48. Diamond, I. K., and N. M. Abeison: The Importance of Rh Inhibitor Substance in Anti-Rh Serums. J. clin. Invest. 24, 122 (1945).

49. Dole, V. P.: A Theory of Moving Boundary Systems Formed by Strong Electrolytes. J. amer. chem. Soc. 67, 1119 (1945).

50. Dutcher, J. D.: Aspergillic Acid: An Antibiotic Substance Produced by Aspergillus Flavus. II. Bromination Reactions and Reduction with Sodium and Alcohol. J. of biol. Chem. 171, 341 (1947).

51. EDsall, J. T.: Chemistry and Clinical Uses of the Protein Components Involved in Blood Clotting. Erg. Physiol. 46, 354 (1950).

52. - The Plasma Proteins and Their Fractionation. Advances prot. Chem. 3, 383 (1947).

53. - R. M. Ferry and S. H. Armstrong jr.: The Proteins Concerned in the Blood Coagulation Mechanism. J. clin. Invest. 23, 557 (1944).

54. - J. F. Foster and H. Scheinberg: Studies on Double Refraction of Flow. III. Human Fibrinogen and Fraction I of Human Plasma. J. amer. chem. Soc. 69, 2731 (1947).

55. - G. A. Gilbert and H. A. Scheraga: The Preparation and Characterization of the Plasma Fraction I-l and Its Nonclotting Component. American Chemical Society, Abstracts of the 112th meeting, Sept. 1947, S. $33 \mathrm{C}$.

56. - and S. G. MILLER: Unpublished observations.

57. Enders, J. F.: Chemical, Clinical, and Immunological Studies on the Products of Human Plasma Fractionation. X. The Concentrations of Certain Antibodies in Globulin Fractions Derived from Human Blood Plasma. J. clin. Invest. 23, 510 (1944).

58. Fitratus, R.: The Suspension Stability of the Blood. Physiol. Kev. y, 241 (1929).

59. Frrguson, J.H.: A New Blood Clotting Theory. Science (Lancaster, Pa.) 97 319 (1943).

60. - Blood Coagulation, Thrombosis, and Hemorrhagic Disorders. Ann. Rev. Physiol. 8, 231 (1946).

61. FERry, J. D., and P. R. Morrison: Chemical, Clinical, and Immunological Studies on the Products of Human Plasma Fractionation. XVI. Fibrin Clots, Fibrin Films, and Fibrinogen Plastics. J. clin. Invest. 23, 566 (1944).

62. - - Fibrin. Film and Other Plastic Products from Human Plasma. Ind. and Chem. Engr. 38, 1217 (1946).

63. - - Preparation and Properties of Serum and Plasma Proteins. VIII. The Conversion of Human Fibrinogen to Fibrin under Various Conditions. J. amer. chem. Soc. 69, 388 (1947). - Preparation and Properties of Serum and Plasma Proteins. IX. Human Fibrin in the Form of an Elastic Film. J. amer. chem. Soc. 69, 400 (1947).

64. Ferry, R. M., E. J. Cohn and E. S. Newman: Studies in the Physical Chemistry of the Proteins. XIII. The Solvent Action of Sodium Chloride on Egg Albumin in $25 \%$ Ethanol at $-5^{\circ}$. J. amer. chem. Soc. 58, 2370 (1936).

65. - - Studies in the Physical Chemistry of the Proteins. XIV. The Solvent Action of Sodium Chloride on Carboxyhemoglobin in 25 and $35 \%$ Ethanol at $-5^{\circ}$. J. amer. chem. Soc. 60, 1480 (1938).

66. FialA, S., and D..Burk: On the Mode of Iron Binding by Siderophilin, Conalbumin, Hydroxylamine, Aspergillic Acid, and Other Hydroxamic Acids. Arch. of Biochem. 20, 172 (1949). 
67. Flosdorf, E. W., and S. Mudd: Procedure and Apparatus for Preservation in "Lyophile" Form of Serum and Other Biological Substances. J. of Immun. 29, 389 (1935).

68. - F. J. Stokes and S. Mudd: The Desivac Process for Drying from the Frozen State. J. amer. med. Assoc. 115, 1095 (1940).

69. Garner, R. L., and W. S. TilletT: Biochemical Studies on the Fibrinolytic Activity of Hemolytic Streptococci. I. Isolation and Characterization of Fibrinolysin. J. of exper. Med. 60, 239 (1934).

70. Gellis, S. S., J. Stokes jr., G. M. Brother, W. M. Hall, H. R. Gilmore, E. BeYER and R.A.MorRissey: The Use of Human Immune Serum Globulin ( $\gamma$-Globulin) in Infectious (Epidemic) Hepatitis in the Mediterranean Theater of Operations. I. Studies on Prophylaxis in Two Epidemics of Infectious Hepatitis. J. amer. med. Assoc. 128, 1062 (1945).

71. Goldstein, A.: The Mechanism of Enzyme-Inhibitor-Substrate Reactions Illustrated by the Cholinesterase-Physostigmine-Acetylcholine System. J. gen. Physiol. 27, 529 (1944).

72. Gray, S. J., and E. B. Mitchell: Effect of Purified Protein Fractions on Sedimentation Rate of Erythrocytes. Proc. Soc. exper. Biol. a. Med. 51, 403 (1942).

73. Greaves, R. I. N., and M. E. AdalR: High-vacuum Condensation Drying of Proteins from the Frozen State. J. of Hyg. 39, 413 (1939).

74. Gutman, A. B.: The Plasma Proteins in Disease. Advances prot. Chem. 4, 155 (1948).

75. HARdy, W. B., and S. Gardiner: Proteins of the Blood Plasma. J. of Physiol. 40, $68 \mathrm{p}$ (1910).

76. Havens, W. P. jr., and J. R. Paul: Prevention of Infectious Hepatitis. J. amer. med. Assoc. 129, 270 (1945).

77. Hegsted, D. M., A. I. HAY and F. J. Stare: Chemical, Clinical, and Immunological Studies on the Products of Human Plasma Fractionation. XXIV. Studies on the Nutritive Value of Human Plasma Fractions. J. clin. Invest. 24, 657 (1945).

78. - J. M. McKibin and F. J. Stare: The Nutritive Value of Human Plasma for the Rat. J. clin. Invest. 23, 705 (1944).

79. Herriott, R. M.: Solubility Methods in the Study of Proteins. Chem. Rev, 30, 413 (1942).

80. Hill, J. M., and D. C. PFeIfFer: A New and Economical Desiccating Proces5 Particularly Suitable for the Preparation of Concentrated Plasma or Serum for Intravenous Use: The Adtevac Process. Ann. int. Med. 14, 201 (1940).

81. Hogness, K. R., J. W. GIFfeE and V. L. Koenig: Electrophoretic Analysis of Bovine Plasma and Serum. Arch. of Biochem. 10, 281 (1946).

82. HolmberG, C. G.: Studies on the Splitting of Fibrin Under the Influence of Fibrinolysin from Haemolytic Streptococci. Ark. Kem., Mineral. Geol. A 17, No 28 (1944).

83. - , and C.-B. LAurell: Investigations in Serum Copper. I. Nature of Serum Copper in its Relation to the Iron-binding Protein in Human Serum. Acta chem. scand. (Stockh.) 1, 944 (1947).

84. Hughes, W. L. jr.: An Albumin Fraction Isolated from Human Plasma as a Crystalline Mercuric Salt. J. amer. chem. Soc. 69, 1836 (1947).

85. Kaplan, M. H., H. J. TAgnoN, C. S. Davidson and F. H. L. TAYLOR: Studies on Blood Coagulation: The Nature and Properties of a Proteolytic Enzyme Derived from Plasma. J. clin. Invest. 21, 533 (1942).

86. KeKwICK, R. A., M. E. MACKAY and B. R. ReCord: Fractionation of Human Plasma with Ether. Nature (Lond.) 157, 629 (1946).

87. Kinkwood, J. G.: Theory of Solutions of Molecules Containing Widely Separated Charges with Special Application to Zwitterions. J. chem. Physics 2, 351 (1934).

88. Klotz, I. M., and F. M. WaLkeR: The Binding of Organic Ions by Proteins. Charge and $\mathrm{pH}$ Effects. J. amer. chem. Soc. 69, 1609 (1947). 
89. KLotz, I. M., and F. M. WALkeR: The Binding of Some Sulfonamides by Bovine Setum Albumin. J. amer. chem. Soc. 70, 943 (1948).

90. - - and R. B. PIVAN: The Binding of Organic Ions by Proteins. J. amer, chem. Soc. 68, 1486 (1946).

91. Koechlin, B.: In preparation.

92. Laurell, C.-B., and B. Ingrlman: The Iron-Binding Protein of Swine Serum. Acta chem. scand. (Stockh.) 1, 770 (1947).

93. Luetscher, J.A. jr.: Electrophoretic Analysis of Plasma and Urinary Proteins. J. clin. Invest. 19, 313 (1940).

94. McFarlane, A. S.: An Ultracentrifugal Investigation of the Serum Proteins. Biochemic. J. 29, 407 (1935).

95. - The Ultracentrifugal Protein Sedimentation Diagram of Normal Human, Cow, and Horse Serum. Biochemic. J. 29, 660 (1935).

96. - Behavior of Lipoids in Human Serum. Nature (Lond.) 149, 439 (1942).

97. Macheboevf, M.: Researches on the Phosphoaminolipids and Steroids of Blood Serum and Plasma. Bull. Soc. Chim. biol. 11, 268 (1929).

98. - État des Lipides dans la Matière Vivante. Paris 1937.

99. Martin, N. H.: Preparation and Properties of Serum and Plasma Proteins. XXI. Interactions with Bilirubin. J. amer. chem. Soc. 71, 1230 (1949).

100. Melin, M.: Chemical, Clinical, and Immunological Studies on the Products of Human Plasma Fractionation. XXV. The Preparation of Anti-A Isoagglutinin Reagents from Mixed Bloods of Groups 0 and B. J. clin. Invest. 24, 662 (1945).

101. Mellanby, J.: Diphtheria Antitoxin. Proc. roy. Soc. Lond. B 80, 399 (1908).

102. Mendel, B., D. B. Mundell and H. Rudney: Studies on Cholinesterase. 3. Specific Tests for True Cholinesterase and Pseudo-Cholinesterase. Biochemic. J. 37, 473 (1943).

103. - and H. Rudney: Studies on Cholinesterase. 1. Cholinesterase and PseudoCholinesterase. Biochemic. J. 37, 59 (1943).

104. Mrchaelis, Leonor: Personal communication.

105. Mirstone, H.: A Factor in Normal Human Blood Which Participates in Streptococcal Fibrinolysis. J. of Immun. 42, 109 (1941).

106. - Purification of Thrombin. J. gen. Physiol. 25, 679 (1942).

107. Mrnot, G. R., C. S. Davidson, J. H. Lewis, H. J. Tagnon and F. H. L. TAYlor: The Coagulation Defect in Hemophilia: The Effect, in Hemophilia, of the Parenteral Administration of a Fraction of the Plasma Globulins Rich in Fibrinogen and Antihemophilic Activity. J. clin. Invest. 24, 704 (1945).

108. Moore, S., and W. H. STEIN: Photometric Ninhydrin Method for Use in the Chromatography of Amino Acids. J. of biol. Chem. 176, 367 (1948).

109. Morrison, P. R.: Preparation and Properties of Serum and Plasma Proteins. XV. Factors Influencing the Quantitative Determination of Fibrinogen. J. amer. chem. Soc. 69, 2723 (1947).

110. - J. T. Edsall and S. G. Miller: Preparation and Properties of Serum and Plasma Proteins. XVIII. The Separation of Purified Fibrinogen from Fraction I of Human Plasma. J: amer. chem. Soc. 70, 3103. (1948).

11. Mulford, D. J.: Derivatives of Blood Plasma. Ann. Rev. Physiol. 9, 327 (1947).

112. Nanninga, L. B.: Investigations on Fibrinogen and Thrombin, the Second Phase of Blood Coagulation. Thesis, University of Amsterdam 1947.

113. Nielsen, L. E., and J. G. KIRKwood: The Fractionation of Proteins by Electrophoresis-Convection. J. amer. chem. Soc. 68, 181 (1946).

14. Northrop, J. H., M. Kunitz and R. M. Herriott: Crystalline Enzymes, 2. Aufl. New York: Columbia University Press 1948.

114a. OnCLey, J. L., F. R.-N. GuRd and M. MeIrN: Preparation and Properties of Serum and Plasma Proteins. XXV. Composition and Properties of Human Serum $\beta$-Lipoprotein. J. amer. chem. Soc, 72, 458 (1950).

$114 \mathrm{~b} . \quad-$ J. T. EDSALI and E. J. CoHn: The Lipoproteins of Human Plasma. Trans. Faraday Soc. 1950. 
115. Oncley, J. L., M. Melin, J. W. Cameron, D. A. Richert and L. K. Diamond: Methods for the Preparation of Anti-A, Anti-B, and Anti-Rh Isoagglutinin Reagents. Ann. N. Y. Acad. Sci. 46, 899 (1946).

116. - - D. A. Richert, J. W. Cameron and P. M. Gross jr.: Preparation and Properties of Serum and Plasma Proteins. XIX. The Separation of the Antibodies, Isoagglutinins, Prothrombin, Plasminogen, and $\beta_{1}$-Iipoprotein Into Subfractions of Human Plasma. J. amer. chem. Soc. 71, 541 (1949).

117. - G. Scatchard and A. Brown: Physical Chemical Characteristics of Certain of the Proteins of Normal Human Plasma. J. Phys. a. Coll. Chem. 51, 184 (1947).

118. Ordman, C. W., C. G. Jennings jr. and C. A. Janeway: Chemical, Clinical, and Immunological Studies on the Products of Human Plasma Fractionation. XII. The Use of Concentrated Normal Human Serum Gamma Globulin (Human Immune Serum Globulin) in the Prevention and Attenuation of Measles. J. clin. Invest. 23, 541 (1944).

119. Pedersen, K. O.: Ultracentrifugal Studies on Serum and Serum Fractions, S. 178. Uppsala: 1945.

120. Perlmann, G. E., and D. Kaufman: The Effect of Ionic Strength and Protein Concentration in the Electrophoretic Analysis of Human Plasma. J. amer. chem. Soc. 67, 638 (1945).

121. Petermann, M. L.: The Splitting of Human Gamma Globulin Antibodies by Papain and Bromelin. J. amer. chem. Soc. 68, 106 (1946).

122. Pillemer, L., J. L. Oncley, M. Melin, J. Elifotit and M. C. Hutchinson: Chemical, Clinical, and Immunological Studies on the Products of Human Plasma Fractionation. XIII. The Separation and Concentration of Isohemagglutinin Reagents from Group-Specific Human Plasma. J. clin. Invest. 23, 550 (1944).

123. Ratr, C. E., and C. A. FINCH: Chemical, Clinical, and Immunological Studies on the Products of Human Plasma Fractionation. XXXVIII. Serum Iron Transport. Measurement of Iron Binding Capacity of Serum in Man. J. clin. Invest. 28, 79 (1949).

124. Roberts, S., and C. M. SzEgo: The Nature of Circulating Estrogen: LipoproteinBound Estrogen in Human Plasma. Endocrinology 39, 183 (1946).

125. Scatchard G. A. C. Batchelder and A. Brown: Preparation and Properties of Serum and Plasma Proteins. VI. Osmotic Equilibria in Solutions of Serum Albumin and Sodium Chloride. J. amer. chem. Soc. 68, 2320 (1946).

126. 一, u. J. G. KIRKwood: Das Verhalten von $Z$ witterionen und von mehrwertigen Ionen mit weitentfernten Ladungen in Elektrolytlösungen. Physik. Z. 33, 297 (1932).

127. - L. E. Strong, W. L. Hughes jr., J. N. Ashworth and A. H. Sparrow: Chemical, Clinical, and Immunological Studies on the Products of Human Plasma Fractionation. XXVI. The Properties of Solutions of Human Serum Albumin of Low Salt Content. J. clin. Invest. 24, 671 (1945).

128. Schade: A. L, and L. Caroline: An Iron-Binding Component in Human Blood Plasma. Science (Lancaster. Pa.) 104, 340 (1946).

129. - - Raw Hen Egg White and the Role of Iron in Growth Inhibition of Shigella Dysenteriae, Staphylococcus Aureus Escherichia Coli, and Saccharomyces Cerevisiae. Science (Lancaster, Pa.) 100, 14 (1944).

130. - R. W. Reinhart and H. Levy: Carbon Dioxide and Oxygen in Complex Formation with Iron and Siderophilin, the Iron-Binding Component of Humath Plasma. Arch. of Biochem. 20, 170 (1949).

131. SeEgers W. H. and E. C. Loomis: Prothrombin and Fibrinolysin. Science (Lancaster, Pa.) 104, 461 (1946).

132. - - and J.M. Vandenbelt: Electrophoresis of Purified Prothrombin. Proc.

133. - - - - Preparation of Prothrombin Products: Isolation of Prothrombin and Its Properties. Arch. of Biochem. 6, 85 (1945). 
134. Sieggers, W. H., H. P. Smith, E. D. Warner and K. M. Brinkhous: The Purification of Prothrombin. J. of biol. Chem. 123, 751 (1938).

135. Shemin, D.: Amino Acid Determinations on Crystalline Bovine and Human Serum Albumin by the Isotope Dilution Method. J. of biol. Chem. 159, 439 (1945).

136. STEIN, W. H., and S. Moore: Chromatography of Amino Acids on Starch Columns. Separation of Phenylalanine, Leucine, Isoleucine, Methionine, Tyrosine, and Valine. J. of biol. Chem. 176, 337 (1948).

136a. - - Amino Acid Composition of $\beta$-Lactoglobulin and Bovine Serum Albumin. J. of biol. Chem. 178, 79 (1949).

137. Stokes, J. jr., E. P. Maris and S. S. Gellis: Use of Concentrated Normal Human Serum Gamma Globulin (Human Immune Serum Globulin) in the Prophylaxis and Treatment of Measles. J. clin. Invest. 23, 531 (1944).

138. - , and J. R. NEEFE: The Prevention and Attenuation of Infectious Hepatitis by $\gamma$-Globulin. J. amer. med. Assoc, 127, 144 (1945).

139. Strong, L. E.: Blood Fractionation. Encycl. Chem. Technology 2 (1948).

140. Strumia, M. M., and J. J. McGraw: A Method and Apparatus for Shell Freezing and Rapid Drying of Plasma and Other Products from the Frozen State by Low Temperature Water Vapor Condensation in Vacuo. J. Labor. a. clin. Med. 28, 1140 (1943).

141. - - and J. Reichel: The Preparation and Preservation of Human Plasma Amer. J. clin. Path. 11, 480 (1941).

142. Surgenor, D. M., and D. Eliss: In preparation.

143. - B. A. Korchiln and L. E. Strong: Chemical, Clinical, and Immunological Studies on Products of Human Plasma Fractionation. XXXVII. The Metal Combining Globulin of Human Plasma. J. clin. Invest, 28, 73 (1949).

144. - L. E. Strong, H. L. TAylor, R. S. Gordon jr. and D. M. Gibson: Preparation and Properties of Serum and Plasma Proteins. XX. The Separation of Choline Esterase, Mucoprotein, and Metal-Combining Protein Into Subfractions of Human Plasma. J. amer. chem. Soc. 71, 1223 (1949).

145. Svedberg, T., and K. O. Pedersen: The Ultracentrifuge. Oxford: Clarendon Press 1940.

146. Svensson, H.: Electrophoresis by the Moving Boundary Method. A Theoretical and Experimental Study. Ark. Kem., Mineral. Geol. A 22, No 10 (1946).

147. TAGNon, H. J:: The Significance of Fibrinolysis in Mechanism of Coagulation of Blood. J. Labor. clin. Med. 27, 1119 (1942).

148. - C. S. Davinson and F. H. L. TAYLOR: Studies of Blood Coagulation: A Proteo lytic Enzyme Prepared from Calcium and Platelet-free Normal Human Blood Plasma. J. clin. Invest. 21, 525 (1942).

149. Taylor, F. H. L., C. S. Davidson, H. J. Tagnon, M. A. Adams, A. H. MacDonald and G. R. MrNor: Chemical, Clinical, and Immunological Studies on the Products of Human Plasma Fractionation. XXVII. Studies in Blood Coagulation. The Coagulation Properties of Certain Globulin Fractions of Normal Human Plasma. In Vitro. J. clin. Invest. 24, 698 (1945).

150. Tillett, W. S., and R. L. Garner: The Fibrinolytic Activity of Hemolytic Streptococci. J. of exper. Med. 58, 485 (1933).

151. Tiselius, A.: A New Apparatus for Electrophoretic Analysis of Colloidal Mixtures. Trans. Faraday Soc. 33, 524 (1937).

152. WARBURG, O., u. W. Christian: Isolierung und Kristallisation des Gärungsferments Enolase. Biochem. Z. 310, 384 (1941).

153. Williams, J. W., M. L. Petermann, G. C. Colovos, M. B. Goodloe, J. L. Oncley and S. H. Armstrong jr.: Chemical, Clinical, and Immunological Studies on the Products of Human Plasma Fractionation. II. Electrophoretic and Ultracentrifugal Studies of Solutions of Human Serum Albumin and Immune Serum Globulins. J. clin. Invest. 23, 433 (1944). 
154. WU, H.: Effect of Removal of Lipoids on Precipitability of Serum Proteins by Neutral Salts. Chin. J. Physiol. 7, 125 (1933-1934).

155. ZelLer, E. A., u. A. BissegGer: Über die Cholin-esterase des Gehirns und der Erythrocyten. Helvet. chim. Acta 26, 1619 (1943).

\section{Introduction.}

The large scale fractionation of the proteins of blood plasma was directly a product of the needs of military medicine in the United States during the war. Fundamentally, however, this development rests on a long series of advances in protein chemistry which have occurred over the last forty years in many laboratories, notably in England, Scandinavia, and the United States. The methods used for the fractionation of proteins depend on the laws governing the solubility of these substances. Our understanding of these laws has been derived, not only from the work of the protein and amino acid chemists themselves, but also from other fundamental studies in the field of pure physical chemistry. All the advances of the last quarter century have been profoundly influenced by two fundamental studies, both published in 1923: the interionic attraction theory of DEBYE and HUCKEL (41) and the convincing demonstration by BJERRUM (11) that amino acids and peptides and, therefore, proteins also exist as dipolar ions in the neutral state. The theory of DEBYE and HückEL, as originally given, provided a basis for calculating the thermodynamic activities and hence the solubilities of electrolytes, as a function of ionic strength, dielectric constant, and temperature. The subsequent extensions of the theory by SCATCHARD and KIRKwood (126) and by KIRKwoon (87) gave the basis for the treatment of dipolar ions along the same lines. Between 1930 and 1940 a large body of experimental evidence was obtained concerning the solubilities of amino acids, polypeptides, and related compounds in relation to their structure. This great body of empirical material could then be evaluated in relation to the theoretical treatments already indicated above, with the additional aid of some empirical generalizations that emerged from the data [for a summary of the work in this field, see the monograph of CoHN and Edsall (35)].

In addition to these achievements, the study of protein chemistry had been revolutionized since 1920 by the introduction of new physical methods for which we are above all indebted to the Upsala laboratories. The development of the ultracentrifuge by SvEDBERG (145), of the modern technique of measuring diffusion constants by LAMM and others in SvEDBERGs laboratory (145), and of the electrophoresis apparatus by TISELIUs (151) have provided indispensable physical tools for the study of every step in the processes of protein fractionation. No one of these tools alone is adequate for the characterization of a protein, nor indeed are all of them together. A protein preparation which appears homogeneous on sedimentation in the ulttacentrifuge may be resolved into several components by study in the 
electrophoresis apparatus, and vice versa. Proteins which are homogeneous by both these tests and perhaps by others as well may still be found to consist of several components when tested by the delicate solubility test of NorTHROP, KunItz, HERRIOTT, and their associates (114).

This brief introduction is intended to emphasize what must never be forgotten: the role of a long period of progress in fundamental science for the development of a conspicuous advance in applied science. The rapid advance of the plasma fractionation program was determined partly by the circumstances of war, but such progress would not have been possible without this fundamental background. It was of necessity a co-operative enterprise involving chemists, medical men, general surgeons, neurosurgeons, immunologists, pathologists, pediatricians, and others. The general story of the progress of these developments has been well told by EDwIN J. CoHN (32), Who was primarily responsible for the initiation and direction of the program. In this article I shall not attempt to cover more than a few aspects of the developments involved; and I shall stress the fundamental chemistry of blood plasma and the methods used in separating it into its components. Before considering these developments in detail, however, one thing Should probably be emphasized above all: namely, the complexity of plasma, regarded as a system of chemical components. This is of course natural since blood plasma is the great highway of transport which carries many molecules from their point of origin in the tissues to other points where they can exert specific action. A partial list of the components of human plasma and some of their properties is given in Table I. Even this table is very much simplified with relation to the known facts. For example, more than 20 antibodies are now known to be present in the $\gamma$-globulin fraction of human $\mathrm{plasma}_{\mathrm{a}}$ and it is almost certain that many other antibodies can be detected if suitable tests are applied. Presumably, all hormones must be present in plasma, although often in concentrations so low as to make their detection impossible, unless the component in question is first separated and concentrated by fractionation. It is this vast complexity of plasma as a physico chemical system which makes necessary the use of many different tools of analysis in the study of the process of protein fractionation. By electrophoresis, for example, one may resolve human plasma into approximately 7 different components, denoted respectively as albumin, $\alpha_{1}$ - and $\alpha_{2}$-globulin, $\beta_{x}$ and $\beta_{2}$-globulin,- fibrinogen (Ø component) and $\gamma$-globulin ${ }^{1}$, in order of decreasing mobility. To a first approximation, each of these appears to move

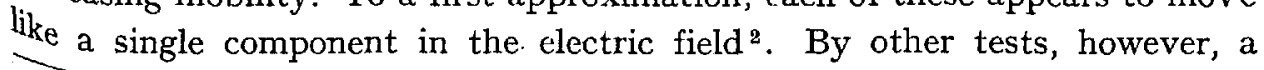

\footnotetext{
${ }^{1}$ Several authors also concluded that the $\gamma$-globulin should be subdivided into $\gamma_{1}$ and $\gamma_{2}$-globulin.

${ }^{2}$ However, recent work of Alberry (2) indicates clearly that the $\gamma$-globulin peak,

afthough not subdivisible into other peaks, is still so broad that it must correspond to

man components of quite widely differing individual mobilities.
} 
Table I. Protein Components of Human Plasma separated and concentrated in Diverse Fractions (31).

\begin{tabular}{|c|c|c|c|c|}
\hline Protein Component & $\begin{array}{c}\text { Estimated } \\
\text { Amount } \\
\text { in } 100 \mathrm{~g} . \\
\text { Plasma } \\
\text { Protein } \\
\text { gms }\end{array}$ & $\begin{array}{l}\text { Concen- } \\
\text { trated in } \\
\text { Fraction }\end{array}$ & \begin{tabular}{|} 
Approx- \\
imate \\
Isoelectric \\
Point
\end{tabular} & $\begin{array}{l}\text { Specific Chemical } \\
\text { Interaction }\end{array}$ \\
\hline Fibrinogen. . . . . . & 4 & $\mathrm{I}-2$ & 5.3 & Thrombin \\
\hline $\begin{array}{l}\text { Non-Clottable Protein, inso- } \\
\text { luble at low temperature }\end{array}$ & 0.15 & I-1 & & \\
\hline Antihemophilic Globulin ${ }^{1}$. & & I & & \\
\hline $\begin{array}{l}\text { Antibody } \gamma \text {-Globulins: } \\
\text { Diphtheria Antibodies } 1 \\
\text { Measles Antibodies } \\
\text { Mumps Antibodies }\end{array}$ & $(0.001)$ & & & \\
\hline $\begin{array}{l}\text { Streptococci Antitoxin }{ }^{1} \\
\text { Influenza Antibodies } \\
\text { Pertussis Antibodies } \\
\text { Typhoid " } \mathrm{H} \text { " Agglutinins }\end{array}$ & 11 & II & 7.3 & Antigens \\
\hline $\begin{array}{l}\text { Antibody Euglobulins } \\
\text { Typhoid " } \mathrm{O} \text { " Agglutinins" }\end{array}$ & & III-1 & & Antigens \\
\hline $\begin{array}{l}\text { Isoagglutinis: } \\
\quad \text { Anti-A, Anti-B }{ }^{1} \quad \cdots \\
\text { Anti-Rh Antibodies }^{1} \ldots\end{array}$ & $(0.03)$ & III-1 J & 6.3 & Incompatible Red Blood \\
\hline 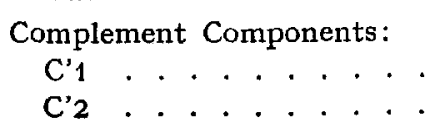 & 0.4 & $\begin{array}{l}\text { III- } 2^{2} \\
\text { IV }^{2}\end{array}$ & & $\begin{array}{l}\text { Cells } \\
\text { Antigen-Antibody } \\
\text { Complex }\end{array}$ \\
\hline $\begin{array}{l}\text { Enzyme Precursors: } \\
\text { Prothrombin . . . . . } \\
\text { Plasminogen . . . . . }\end{array}$ & 0.3 & $\begin{array}{l}\text { III-2 } \\
\text { III-3 }\end{array}$ & & $\begin{array}{l}\text { Thromboplastin } \\
\text { Streptokinase }\end{array}$ \\
\hline 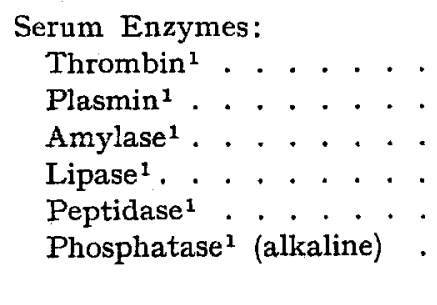 & & $\begin{array}{l}\text { III-2 } \\
\text { III-3 }\end{array}$ & 4.8 & $\begin{array}{l}\text { Fibrinogen } \\
\text { Proteins } \\
\text { Starch } \\
\text { Lipid } \\
l \text {-Leucylglycylglycine } \\
\text { Phosphoric Acid Mono- } \\
\quad \text { esters }\end{array}$ \\
\hline $\begin{array}{l}\text { Esterase }^{1} \cdot \cdots \\
\text { Metal-Combining } \beta_{1} \text {-Pseudo- }\end{array}$ & 0.02 & IV-6 & 4.5 & $\begin{array}{l}\text { Acetyl Choline, Ethyt } \\
\text { butyrate }\end{array}$ \\
\hline $\begin{array}{l}\text { globulin: crystallized. . } \\
\text { High Molecular Weight }\end{array}$ & 2.5 & IV-7 & 5.6 & Iron and Copper \\
\hline $\begin{array}{l}\beta_{1} \text { Globulins (Lipid-poor) } \\
\mathrm{S}=7 \quad . \quad . \quad . . . \\
\mathrm{S}=20 .\end{array}$ & $\begin{array}{l}2 \\
1\end{array}$ & $\begin{array}{l}\text { III-0 } \\
\text { III-0 }\end{array}$ & & \\
\hline Iodoprotein ${ }^{1,8}$. . . . . & & IV-6 & & \\
\hline Thyrotropic Hormone ${ }^{1}$ & & IV-4 & & \\
\hline $\begin{array}{l}\text { Glycoproteins: } \\
\alpha_{2} \text {-Glyco-pseudoglobulin . } \\
\alpha_{2} \text {-Mucoid Globulin . . . }\end{array}$ & $\begin{array}{l}0.7 \\
0.5\end{array}$ & $\begin{array}{l}\text { IV-6 } \\
\text { IV-6 }\end{array}$ & $\begin{array}{l}4.9 \\
4.9\end{array}$ & \\
\hline
\end{tabular}


Table I (Continuation).

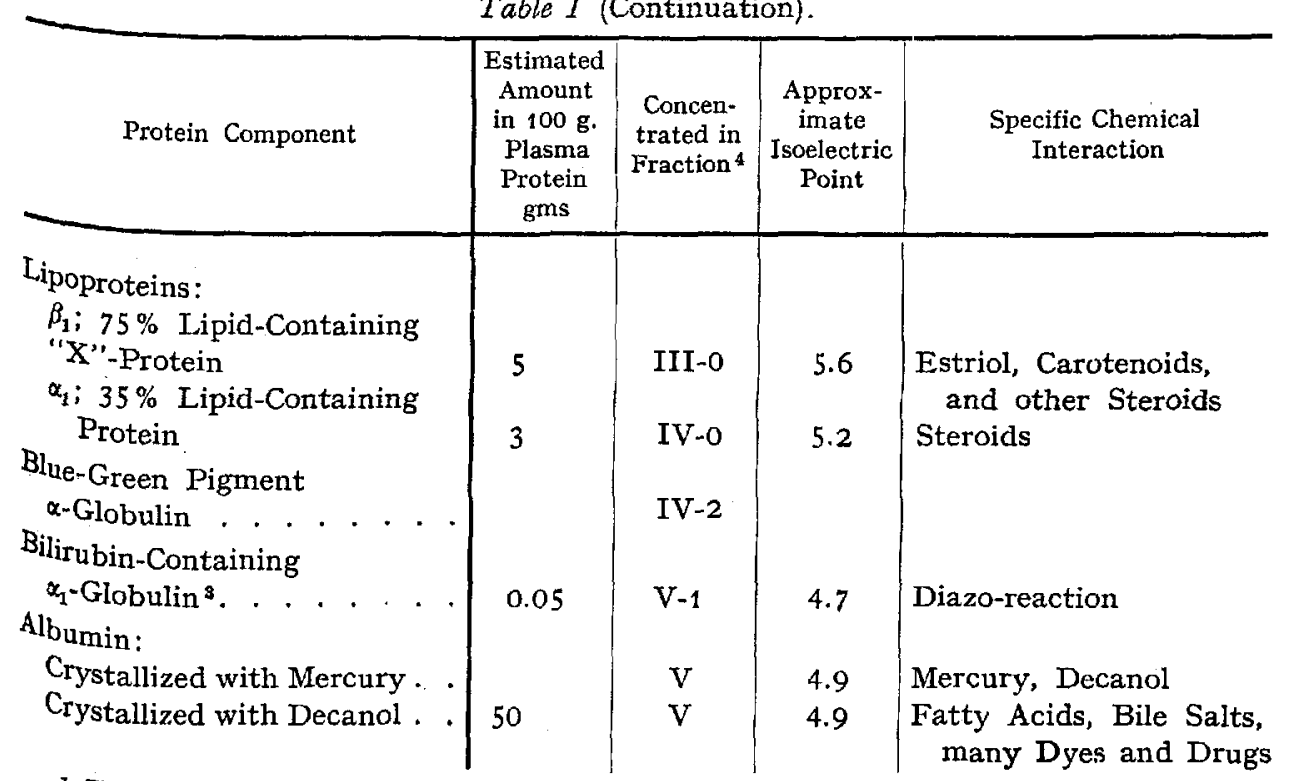

${ }^{I}$ These components represent but small proportions of the fraction and subfraction,

and their properties cannot, therefore, be deduced from those of the concentrates in

Which they have been separated.

2 These components have not been tested for since revision of the fractionation process.

3 Albumin binds more bilirubin than the bilirubin pigment globulin in Fraction V-1

and more iodine than has been found in Fraction IV-6.

4hen purified chemical components have been separated from fractions they

have not been given new fraction numbers. In that case, the fraction number refers to

the starting material for the separation of the component.

drastic resolution of some of these components can be obtainer. For example, at least four chemically separable protein components are known, all of which move in the electric field with the characteristic mobility of $\beta_{1}$-globulin. One of these is a very large lipoprotein molecule containing far more lipid material than amino acid residues. Another is a much smaller molecule quite free of lipid, characterized by its specific capacity to bind iron. These are readily separated by chemical fractionation, once the proper conditions for separation are known. This is only one of many examples of the great variety of components in the blood plasma which are beginning to be resolved from one another by increasingly discriminating methods of fractionation.

\section{Some General Aspects of Fractionation by Means of Ethanol at Low Temperature and Low Ionic Strength.}

In the past the most widely used general method of separating proteins from complex mixtures has been salting out in concentrated solutions of Deutral salts, such as ammonium sulfate, sodium sulfate, or potassium phosPhate buffers ${ }^{1}$. In the salting out method, the system may be characterized

\footnotetext{
${ }^{1}$ For a general review of this background, see for example Edsall (52).
} 
by four major variables: namely, salt concentration, protein concentration, $\mathrm{pH}$, and temperature. A wide range of possible combinations of these variables is obtainable in any given fractionation process, which gives a great deal of scope for the separation of numerous components from the complex systems existing in nature. Restrictions on the range of variation of these variables are of course imposed by the requirement that the protein components of the system shall be separated in a form as nearly undenatured as possible. Nevertheless, the possible range of experimental condition is wide.

However, salting out methods have certain limitations. The action of concentrated salt solutions in precipitating proteins is largely a function of the general size and shape of the protein molecule; whereas at low ionic strengths the dipole moment of the molecule and other characteristics determined by the number and distribution of the electrically charged and uncharged amino acid residues have a profound and often highly specific influence, varying greatly from one protein to another. Separations at low ionic strengths, therefore, can frequently be made sharper and more specific than those carried on at high ionic strength by salting out. However, in order to work at low ionic strength it is necessary, in order to precipitate proteins like the albumins, to lower the dielectric constant of the medium by the addition of some organic solvent such as methanol, ethanol, or acetone. These reagents, however, act as powerful denaturing agents for many proteins at ordinary temperatures. In order to make fractionation, therefore, as safe as possible with the use of these reagents, it is necessary to work at low temperatures, generally below $0^{\circ} \mathrm{C}$.

Fractionation by a procedure of this sort permits, in many respects, a wider range of possible conditions than those obtainable with the salting out methods. Instead of four variables, at least five are now required to determine the state of the system: namely, $\mathrm{pH}$, temperature, ionic strength, protein concentration, and concentration of ethanol or other organic precipitant. The introduction of a fifth variable into the system increases enormously the possible range of variation in experimental conditions for separation. This increased freedom is partly counterbalanced by the strict requirement of maintenance of low temperature. However, the scope of the method is so wide that it has permitted in many cases the separation of protein components which had not been resolved by the salting out techniques, and the range of possible future fractionation procedures, not only on blood plas $\mathrm{m}^{2}$ but also on many other tissues, appears to be much greater than anything yet achieved ${ }^{1}$.

1 The discussion given here is necessarily brief. Various other aspects of the significance of this method of fractionation and the products obtained by it are given by Conn $(28,29,30,31,34)$, Strong (139), Mulford (111), and Brand and Edsall (17). A detailed history of these developments is given by CoHn (32). An extensive review of the plasma proteins in disease has recently been given by GuTMan (74). 
For large scale fractionation of proteins, the low salt-ethanol method has another advantage over the salting-out procedures. In the latter, the high salt concentrations necessary for protein precipitation can be diminished only by dialysis, a procedure which is time consuming and involves much work when a large volume of liquid is to be dialyzed. Furthermore, during the later steps of dialysis when the salt concentration is diminished, conditions become favorable for bacterial growth, and the protein solution is likely to become contaminated. If ethanol or acetone is used as a precipitant, instead of salt, it may be readily removed because of its volatility. By far the safest method for such removal appears to be the rapid freezing of the solution at very low temperature with subsequent drying from the frozen state in a vacuum. The cooling produced by evaporation maintains the frozen protein solution at low temperature through almost the whole of the process, and the temperature begins to rise only when the protein is nearly dried. Under these circumstances, most of the plasma proteins, and a great many other proteins, are found to be completely soluble in water or dilute salt solutions after drying is complete, and they may be preserved in the dry state without alteration for long periods of time. Certain proteins indeed - in blood plasma these include particularly the lipoproteins - can not be dried without denaturation, and for their purification dialysis may be necessary at certain steps in the procedure. However, serum albumin, fibrinogen, and most of the globulin components of plasma can be dried from the frozen state without impairing their solubility or their specific properties'.

Combined with these advantages, the method also has certain definite dangers. Although variation in temperature can often be used to separate certain components with a large heat of solution, the upper limit of the temperatures employed in such a system must be low, in order to avoid denaturation of the protein. In all systems of plasma protein fractionation employed since 1940 at the Plasma Fractionation Laboratory, the temperature at every step has been held at or below $0^{\circ} \mathrm{C}$. As soon as sufficient alcohol has been added, the temperature is reduced below $0^{\circ} \mathrm{C}$; ; and in all steps at which the alcohol concentration is greater than $20 \%$ by volume, the temperature is maintained at or below $-5^{\circ} \mathrm{C}$. Special precautions are needed to insure that the temperature is held at these assigned levels at every stage during the process. The mixing of alcohol and water is attended with evolution of heat. It is therefore important, not only that the ethanol addition should be carried out in cold surroundings, but it is further necessary to insure additional cooling during the mixing of ethanol and water. If the process is

I The technique of drying proteins from the frozen state cannot be discussed here for lack of space. The following references may be consulted: FiosDorF and MuDD (67), Flosdorf, Stokes, and Mudd (68), Greaves and Adair (73), Hill and Pfeiffer (80), STrumia, McGraw, and Reichel (141), Strumia and McGraw (140). 
carried out" on a small scale, this may be done by immersing the container in a low temperature bath, and stirring constantly to attain temperature equilibrium between the liquid in the container and the bath outside. Containers made of stainless steel are advantageous for this purpose because of their high heat conductivity. When large scale processing is carried on, the precipitations are usually carried out in large glass lined tanks in a cold room. Cooling during the addition of ethanol can be achieved in such cases by the circulation of refrigerant through a spiral coil of stainless steel tubing, immersed in the plasma solution. Here again, constant stirring is necessary during the addition of ethanol, which must in all cases proceed slowly, 15ually by inflow through capillary tubing. Rapid stirring is essential here in order to prevent any element of the protein solution from attaining, even temporarily, an unduly high ethanol concentration which might denature the protein.

These precautions concerning temperature and the method of the addition of ethanol are of major importance. It has been found by experience in this laboratory during processing that even a brief rise of temperature to a few degrees above $0^{\circ}$ for a $f \cdot w$ minutes may have definite and undesirable effects on the stability of the end product obtained by fractionation. While it is true that certain proteins appear to resist exposure to considerable ethanol concentrations, even at room temperature, with little or no sign of denaturation, it must still be considered that such proteins are the exception rather than the rule. Even when denaturation is undetectable by most tests, sufficiently careful observations may indicate that some of the protein molecules have become altered. Rigorous precautions should be taken to insure the maintenance of low temperatures, in any protein system involving such reagents as ethanol or acetone, until clear and definite proof has been obtained that the proteins under investigation can be safely precipitated in such media at a higher temperature. The necessity for these precautions in fractionation by the low temperature, low salt, ethanol method makes it in many respects a more difficult process to carry out than is fractionation by salting-out with ammonium sulfate. The necessary precautions are fundamentally simple, but they must be strictly maintained and not relaxed in any step in the process. Once the proper design of apparatus and equipment has been obtained, however, and provided the workers operating the process understand the necessity for these precautions, it is possible to carry through a quite elaborate fractionation procedure with a group of workers with a relatively rudimentary knowledge of science and technology, provided that their director be a competent supervisor. This has been abundantly proved by the success of the large scale fractionation of blood plasma during the war, utilizing these methods in a group of seven different pharmaceutical houses. 


\section{Choice of Conditions in the Fractionation of Plasma.}

Alcohol, acetone, ether, and other related reagents had, of course, been constantly employed, beginning early in the nineteenth century, by protein chemists to precipitate proteins, to wash them free of impurities, and prepare them for analytical study. For the analytical chemist the accompanying denaturation of the protein was not generally a matter of concern, provided no small fragments of the native protein molecules were split off and washed away by the treatment, before analysis was begun. For preparation of undenatured proteins by such reagents, however, precautions of the sort described above were essential, and these were seldom taken. One of the first relatively successful uses of alcohol in this connection was the concentration of diphtheria antitoxin by ethanol precipitation in the cold, as employed by MEILANBy (101) in 1908. This was also one of the earliest publications in which the protein nature of an antibody was definitely claimed. Two years later, HARDY and GARDINER (75) published a brief account of experiments of fundamental importance, involving the precipitation of plasma proteins with ethanol (or acetone) at low temperature, and their subsequent Washing with ethanol and ether to remove lipids. The resulting dried protein preparations readily redissolved to give clear and stable solutions in water or physiological saline. The achievement of such dried preparations represented a major advance in protein chemistry; however, later studies with the ultracentrifuge have revealed that the removal of lipids by the alcoholether techniques is accompanied by marked changes in the sedimentation diagram [McFarLane $(94,95)$ ]; Pedersen (119), especially pp. 43-51 incl.]. The alterations in the lipoproteins of native plasma which this treatment must produce would be expected to be drastic, in the light of our present knowledge, so that these findings are not surprising 1 .

WU (154) successfully employed low temperature-ethanol precipitation in the preparation of undenatured proteins; and FERRY, COHN, and NEWMAN (64, 65) employed ethanol-water, at $-5^{\circ} \mathrm{C}$, at low ionic strengths, as a medium for studying the solubility of egg albumin and horse hemoglobin in solvents of low dielectric constant. They showed that the solvent action of neutral salts under these conditions was much greater than in water; and that both these proteins could be successfully recrystallized, after exposure to $15-25$ per cent ethanol at $-5^{\circ}$ for long periods, provided the ethanol was removed before the temperature was raised.

The first report on a systematic fractionation of plasma by the low temPerature-low salt-ethanol procedures was made in 1940 by CoHN, LUETSCHer,

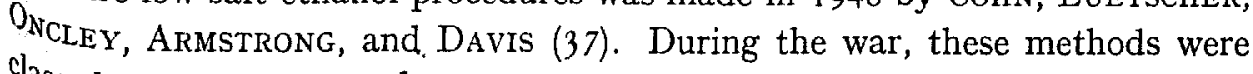
Classed as confidential, and a very long series of plasma fractionation runs Was made, using human blood, collected by the American Red Cross, in

\footnotetext{
${ }^{1}$ Concerning the lipoproteins of plasma, see p. 344.
} 
connection with the development of plasma fractionation products for use by the Armed Forces ${ }^{1}$. Much information concerning the nature of the products obtained, and their clinical uses, was released during the war ${ }^{2}$, but the first detailed report of the methods used was given in 1946 by Corn, Strong, Hughes, Mulford, Ashworth, Meidn, and Taylor (39). An earlier report (38) [see also (153)] gave many details concerning the properties of the plasma fractions.

The methods of plasma fractionation, as developed at the present time, represent a gradual evolution, based on the attempt to develop an inclusive process which should yield all the components of plasma in active, concentrated, and undenatured form. This goal, of course, is still far from achieve ment, but the later processes have represented a great advance over the earliet ones, both with respect to the number and specificity of the active fractions separated, and with respect to the preservation of components in undenatured form.

Certain properties of the protein components of human plasma have been recognized, as experience was accumulated, and formed the basis of the plasma fractionation process employed at present. Some of them may be stated as follows: (1) Most of the fibrinogen is readily precipitated at very low ethanol concentrations ( 8 to $10 \%$ by volume), at temperatures between $0^{\circ}$ and $-3^{\circ} \mathrm{C}$, and $\mathrm{p}_{\mathrm{H}}$ values near 7 . The fraction so obtained is known as Fraction I. (2) Virtually all the $\gamma$-globulin, and a large portion of the $\beta$-globulin, including the $\beta_{1}$-lipoprotein (X-protein), is precipitated on raising the ethanol concentration to $25 \%$ by volume, while lowering the temperature to $-5^{\circ} \mathrm{C}$ at $\mathrm{p}_{\mathrm{H}}$ near 7 . This fraction, designated as II + III, also contains prothrombin and the isoagglutinins. These various components are separated by methods described later. (3) A large portion of the a-globulin, much of it a lipoprotein containing about $35 \%$ lipid (cholesterol, fatty acid, phosphatide), can be separated from the supernatant of Fraction II + III by lowering the ethanol concentration to $18 \%$ and the $\mathrm{p}_{\mathrm{H}}$ to 5.2 . This fraction is denoted as IV-1. Another component of this fraction is a blue-green pigment, previously described by Luetscher (93) and others. In the earlier procedures employed for fractionation [see (39)] the $\alpha$-lipoprotein was largely denatured, and the lipid removed from its attachment to the protein conponent, by carrying out the precipitation at higher alcohol concentration

1 This work was originally supported by grants from the Rockefeller Foundation and from funds of Harvard University. It was aided early in 194 by grants from the Committee on Medicine of the National Research Council, which included a grant from the American College of Physicians. From August, 1941, to July, 1946, it was carried out under contract, recommended by the Committee 'on Medical Research, between the Office of Scientific Research and Development and Harvard University.

2 See particularly a series of papers in the Journal of Clinical Investigation $2^{3}$, $417-606$ incl. (1944); 24,657,662,671,698, 704, 793, 802, (1945). Many of these papers are referred to separately in the bibliography. 
$(40 \%)$ and $\mathrm{p}_{\mathrm{H}} 5.5-5.8^{1}$. It was found, however, that the protein could be prepared in a distinctly more soluble form in which the lipid was still attached to the protein if this material was never exposed to ethanol concentrations higher than $25 \%$, its precipitation being readily brought about in $18 \%$ ethanol because of its rapidly decreasing solubility with decrease of $\mathrm{p}_{\mathrm{H}}$ between 6 and 5.2. (4) The supernatant from Fraction IV-1 contains other $\alpha$-globulins, virtually lipid-free, certain $\beta$-globulins, and nearly all the albumin. To separate the globulins, while leaving the albumin in solution, the ethanol concentration is raised to $40 \%\left(0.163 \mathrm{~mol}\right.$ fraction ethanol) and the $p_{\mathrm{H}}$ to 5.8 . The resulting precipitate (Fraction IV-4) contains some albumin and $\alpha$ - and $\beta$-globulins. The latter include serum esterase and a specific iron binding globulin of plasma. (5) The protein in the supernatant from Fraction IV-4 is almost entirely albumin. It is now separated by lowering the $\mathrm{p}_{\mathrm{H}}$ to 4.8 , with $\mathrm{P}_{\mathrm{H}} 4$ acetate buffer ${ }^{2}$, while maintaining the ethanol concentration at $40 \%$. The albumin is practically isoelectric, under these conditions, and precipitates almost quantitatively as Fraction $V$. The albumin in the resulting precipitate contains about $4 \%$ of $\alpha$ - and $1 \%$ of $\beta$-globulin, which are less heat-stable than the albumin. They can be largely removed by redissolving the precipitate in water, and adding ethanol to a volume concentration of $10 \%$ at $-3^{\circ}$, at $\mathrm{P}_{\mathrm{H}}$ 4.6, and ionic strength 0.01 . The resulting small precipitate is filtered off, and the filtrate contains albumin of $97-99 \%$ purity, as judged from electrophoresis in $\mathrm{p}_{\mathrm{H}} 8.6$ barbiturate buffer. The globulin content can be reduced to a few tenths of one per cent, or less, by crystallization of the albumin, as described later.

The supernatant solution from Fraction $V$, when concentrated by evaporation at low temperature, is known as Fraction VI. It contains a very small amount of albumin and $\alpha$-globulin (less than $2 \%$ of the total protein in plasma), large amounts of salt, and some of the low molecular weight non-protein substances found in plasma.

The conditions for separation of the principal fractions of human plasma, and the electrophoretic data concerning them, are summarized in Table II. The procedure for separation here described is known as method 6; it has evolved from a series of earlier methods described in detail elsewhere (39),

${ }^{1}$ Some evidence very recently obtained, however, indicates that the $\alpha$-lipoprotein as separated in Fraction IV-1 by this procedure has been altered from its original state in plasma and could not be properly called undenatured. Work on this problem by Professor CoHN and his associates is now in progress.

${ }^{2}$ The $\mathrm{p}_{\mathrm{H}}$ values are not measured directly on the solution of high ethanol content, but are determined on the glass electrode after diluting the solution with water, or preferably dilute sodium chloride solution $(0.02 \mathrm{M})$, to a final content of about $4 \%$ ethanol. Acetate buffer is used, rather than acetic acid, so that the protein solution is never exposed, even momentarily, to $\mathrm{P}_{\mathbf{H}}$ values more acid than 4 . The preparation of acetate buffers, of a given $\mathrm{P}_{\mathrm{H}}$ and ionic strength, is conveniently made with the aid of the nomogram given by Boyd (13). 
and is obviously subject to further modification and improvement. Moreover, it should be emphasized that the method as described, and the data obtained, apply specifically only to human plasma. Plasma from other species invariably shows characteristic differences which will be reflected in the fractionation. The $\beta_{1}$-lipoprotein (X-protein of PEIERSEN (119)] found in Fraction II + III, for instance, has been recognized only in human plasma; a protein of this type has been found only in traces, if at all, in the animal plasmas hitherto examined. The details of the plasma fractionation procedure may therefore require important modifications, depending on the species of plasma being fractionated.

Table 11. Separation and Electrophoretic Composition of Principal Fractions of Human Plasma by Method 6.

\begin{tabular}{|c|c|c|c|c|c|c|c|c|c|c|c|}
\hline \multirow{3}{*}{$\odot /$ Fraction } & \multicolumn{5}{|c|}{ Conditions of Separation } & \multirow{2}{*}{\multicolumn{6}{|c|}{$\begin{array}{l}\text { Electrophoretic Composition } \\
\text { g. per Liter of Plasma Estimated in Plasma }\end{array}$}} \\
\hline & \multirow{2}{*}{$\mathrm{P}_{\mathbf{n}}$} & \multirow{2}{*}{$\Gamma / 2$} & \multirow{2}{*}{$\begin{array}{c}\text { Temp. } \\
{ }^{\circ} \mathrm{C} .\end{array}$} & \multirow{2}{*}{$\begin{array}{l}\text { Mole./ } \\
\text { Fraction } \\
\text { Ethanol }\end{array}$} & \multirow{2}{*}{$\begin{array}{c}\text { Protein } \\
\text { in } \\
\text { System, } \\
\text { g./l. }\end{array}$} & & & & & & \\
\hline & & & & & & $\begin{array}{l}\text { Albu- } \\
\text { min }\end{array}$ & $\alpha$ & $\beta$ & $\gamma$ & $\begin{array}{l}\text { Fibri- } \\
\text { nogen }\end{array}$ & Total \\
\hline Plasma & 7.4 & .16 & .. & .. & 60.3 & 36.3 & 9.2 & 10.6 & 7.2 & 2.5 & 65.8 \\
\hline I & 7.2 & .14 & -3 & .027 & 51.1 & 0.2 & 0.3 & 0.5 & 0.3 & 2.1 & 3.4 \\
\hline$I I+I I I$ & 6.8 & .09 & -5 & .091 & 30.0 & 0.8 & 1.1 & 9.1 & 7.0 & 1.0 & 19.0 \\
\hline IV -1 & 5.2 & .09 & -5 & .062 & 15.8 & 0 & 4.5 & 0.5 & 0.1 & 0 & 5.1 \\
\hline IV -4 & 5.8 & .09 & -5 & .163 & 10.1 & 0.9 & 2.7 & 2.2 & 0 & 0 & .8 \\
\hline $\mathrm{V}$ & 4.8 & .11 & -5 & .163 & 7.5 & 29.9 & 1.3 & 0.3 & 0 & 0 & 31.5 \\
\hline VI & 4.8 & .11 & -5 & .163 & 0.2 & 0.8 & 0.2 & $<.1$ & 0 & 0 & 1.0 \\
\hline Total & $\ldots$ & $\ldots$ & $\ldots$ & $\ldots$ & $\ldots$ & 32.6 & 10.1 & 12.6 & 7.4 & 3.1 & 65.8 \\
\hline
\end{tabular}

Data from Cohn, Strong, Hughes, Mulrokd, Ashworth, Melin and Taylor (39); see specially Tables II and IX of their paper. Electrophoretic figures in the top row are for measurements directly on plasma; those in the bottom row are summations from the distribution in the plasma fractions, multiplying by the appropriate factor for the percentage of total plasma protein represented in the fraction.

Electrophoretic components of plasma with mobilities close to that of fibrinogen are resolved with difficulty. The value of $2.5 \mathrm{~g} .1$, for fibrinogen in whole plasma is derived from Edsall, Ferry and ARMstrong (53), who base their estimates on the amount of protein clottable with thrombin [see also MorRIson (109)]. The remainder of the protein with the same mobility is included with the $\beta$-globulins. A similar situation occurs with Fraction II + III.

Satisfactory resolution of the $\alpha_{1}$-globulin from albumin in Fraction IV-1 has not been accomplished, and since probably less than $25 \%$ of the fraction is albumin, any components with mobilities similar to that of albumin have been included with the $\alpha$-globulins. Further studies on this point are in progress.

For some purposes the principal fractions can be employed as such. For instance, Fraction $I$ is a suitable starting material for the preparation of fibrin foam and film; and Fraction $V$, after a single reprecipitation, as already described, can be dissolved in a solution containing a suitable stabilizing agent, such as the sodium salt of acetyl-tryptophan at $0.04 M$, to give ${ }^{2}$ concentrated solution of high stability which has found extended clinical use. 
The Subfractionation of Fraction I: Fibrinogen and the Anti-Hemophilic Globulin. 327

However, for many purposes further subfractionation of the principal fractions is essential, in order to obtain separately the many important components they contain.

\section{The Subfractionation of Fraction I: Fibrinogen and the Anti-Hemophilic Globulin.}

Fraction I as first separated from human plasma contains approximately 60 to $65 \%$ fibrinogen ${ }^{1}$. This factor is determined more specifically by measuring the amount of protein from the fraction which will form a fibrin clot with thrombin. To give reliable results for fibrinogen assay, the clot must be formed under suitably chosen conditions of $\mathrm{p}_{\mathrm{H}}$, ionic strength, and fibrinogen and thrombin concentration. A systematic study of these factors has been made by MORRISON (109) ${ }^{2}$.

Fraction I, although very far from being pure fibrinogen, has served as an excellent starting material for the preparation of many fibrinogen and fibrin products, such as fibrin foam and fibrin film $(10,61,62,63)$. However, for a deeper understanding of the clotting process, and for chemical studies of the fibrinogen molecule, a much more highly purified fibrinogen is essential. Recent studies (110) have shown that two characteristics of the protein in Fraction I are particularly important for this separation: (1) The solubility of fibrinogen decreases more rapidly with decrease in $p_{H}$, between $p_{H} 5$ and 7 , than that of the non-clottable protein of Fraction I. (2) The temperature coefficient of solubility is very large, both for fibrinogen and for the nonclottable protein. However, there is one portion of the non-clottable protein with an extremely high temperature coefficient of solubility, which can be conveniently separated by lowering the temperature of a concentrated Fraction I solution from $10^{\circ}$ or above to approximately $0^{03}$. A certain amount of fibrinogen is lost in this separation, but the residual more soluble material has a much higher fibrinogen content than the original Fraction I. Making use of these observations, human fibrinogen preparations containing $98 \%$ of clottable protein, or better, have been obtained.

I The fibrinogen content of bovine Fraction I is generally $75 \%$ or better, reflecting the much higher concentration of fibrinogen in bovine plasma $(45,81)$.

${ }^{2}$ Misleading results can, of course, be given if other plasma proteins are occluded in the clot as it forms. Morrisons studies have shown that the lipoprotein Fractions III-0 and IV-1 have especially high tendencies to occlusion; the non-clottable protein of Fraction $I$ is also occluded more than most of the other plasma protein components. Albumin is virtually not occluded at all. Morrisons findings on occlusion have an obvious significance for the assay for fibrinogen in whole plasma, particularly in some pathological plasmas containing high concentrations of lipids and lipoproteins.

3 The properties of this non-clottable protein, which we have tentatively denoted as cold insoluble globulin, have been studied by EDSALL, Gilbert, and ScheraGa (55). The molecule appears to be of approximately the same length as fibrinogen but with larger cross section and approximately twice the molecular weight. 
Hum an fibrinogen is a very large elongated molecule with a length of the order of $700 \AA$, as judged by double refraction of flow studies (54). Its sedimentation constant $s_{20}$, is approximately $9 \mathrm{~S}$ as reported by both ONCLEY, Scatchard, and Brown (117) (see Table V, p. 347) and Holmberg (82). HoLMBERG estimates the molecular weight as near 700,000 from sedimentation and diffusion, while ONCLEY gives a figure of approximately 400,000, based on sedimentation, viscosity, and double refraction of flow. EDSALL, FosTER, and ScHeinberg (54) have made a critical comparison of all the data on human fibrinogen and conclude by giving an approximate molecular weight of the order of 460,000 . Within the present limits of experimental error, this may be taken as in close agreement with OnCLEYs estimate. NANNINGA (112) has studied bovine fibrinogen by osmotic pressure and viscosity measurements. $\mathrm{He}$ deduces a molecular weight of 440,000 and a length of approximately $725 \AA$, in remarkably close agreement with the values on human fibrinogen.

Fraction I of normal plasma contains a high concentration of another component, at present recognizable only through its influence in shortening the clotting time of hemophilic blood, even when added at very high dilution. This factor is also present in Fraction III-2,3 which contains prothrombin and plasminogen, but the concentration is far higher in Fraction I. Preparations of Fraction I, dried from the frozen state in sterile form, have been used clinically by a number of investigators to shorten clotting time in hemophilic patients who were about to undergo an operation, or who were suffering from internal bleeding. In many cases, the treatment has proved strikingly effective. The results are, of course, only temporary and are essentially identical with those which can be obtained by injections of compatible whole blood or plasma $(107,149)$. A few hemophilic patients, who respond to whole plasma, are not benefited by Fraction I injections.

As yet all attempts to separate the antihemophilic factor from fibrinogen by chemical means have proved unsuccessful. The two are clearly distinct; fibrinogen, for instance, is readily heat coagulated in 5 minutes at $53^{\circ}$, whereas the antihemophilic activity of Fraction $I$ is still high after this heat treatment, although it is rapidly lost at $65-70^{\circ} \mathrm{C}$. Further research on the chemical nature of the antihemophilic factor is clearly necessary.

\section{Subfractionation of Fraction II + III.}

This fraction contains virtually all the antibodies of plasma, as well as prothrombin, the isoagglutinins, plasminogen, and the component $\mathrm{C}_{1}^{\prime}$ of complement. The separation of these various components is, of course, of major importance, and a systematic procedure has been developed by ONCLEY, Melin, Cameron, Richert, and Gross (116). Briefly, it is based on the following observations: 
1. The $\beta_{1}$-lipoprotein ( $\mathrm{X}$-protein) is soluble at $\mathrm{p}_{\mathrm{H}} 7.2-7.6$ even at relatively high ethanol concentrations $(17-20 \%)$, whereas nearly all other components of this fraction are insoluble under these conditions if the ionic strength is sufficiently low. The removal of the lipoprotein, as the first step in the subfractionation process, enables it to be separated without denaturation, and allows the subsequent separation of all the other components of Fraction II + III in virtually lipid-free condition.

2. Prothrombin, plasminogen, and the fibrinogen not already precipitated in Fraction $I$, are very insoluble at $p_{H} 5.2-5.4$, even in the absence of alcohol and at moderately high ionic strengths. This fraction is denoted as III-2, or III-2,3.

3. The isoagglutinins are also insoluble at $\mathrm{p}_{\boldsymbol{H}} \quad 5.2-5.4$ at very low ionic strengths, but dissolve readily at this $\mathrm{p}_{\mathrm{H}}$ on slightly increasing the ionic strength to a value insufficient to dissolve prothrombin, fibrinogen, or plasminogen. The $\mathrm{p}_{\mathrm{H}}$ of minimum solubility for the isoagglutinins is near 6.3 ; they are readily precipitated at this $\mathrm{p}_{\mathrm{H}}$, at low salt and low ethanol concentrations, the resulting fraction being known as III-1.

4. Most of the $y$-globulins are least soluble at $\mathrm{p}_{\mathrm{H}}$ values near 7 . At $\mathrm{p}_{\mathrm{H}}$ 5.2-5.4 they are very soluble, probably more soluble than any other component of plasma at this $\mathrm{p}_{\mathrm{H}}$ and at low ionic strength. One portion of the $\gamma$-globulins (Fraction II-3) is precipitated in this $\mathrm{p}_{\mathrm{H}}$ region by a moderate increase of lonic strength; it thus belongs to the class of proteins which are salted out, even at low ionic strength, on the acid side of the isoelectric point. The remainder - the major part of the $\gamma$-globulin (Fraction II-1, 2) - is precipitated most readily near to, or slightly above, $\mathrm{p}_{\mathrm{H}} 7$, at ethanol concentrations near $20 \%$ at $-5^{\circ} \mathrm{C}$.

5. Plasminogen is strongly adsorbed on a fibrin clot, if the clot is formed in a solution containing plasminogen.

The steps in the subfractionation of Fraction II + III (116) will not be discussed in detail here, but are shown diagrammatically in Fig. 1.

Fo give some notion of details of procedure, the first step in the process shown in Figure 1 has been described as follows:

"Each kilogram of precipitate II + III is suspended in 2 kilograms of water containing ice (about one-quarter of the water should be frozen, in the form of very fine ice crystals). When this suspension is fairly uniform, add 3 kilograms of $0^{0}$ water to which ${ }_{112} \mathrm{cc}$. of $0.5 \mathrm{M} \mathrm{Na} \mathrm{HPO}_{4}\left(\mathrm{p}_{\mathrm{H}}\right.$ 9.2) has been added. This suspension should be stirred \$lowly and kept at a temperature of $0^{\circ} \mathrm{C}$. until all lumps are dissolved, and a nearly $c_{m}$ plete solution is obtained. After the suspension is complete, add it to 20 kilograms of $0^{0}$ water and stir slowly at $0^{0}$ for $30-60$ minutes. The $p_{H}$ of this suspension should read $7.2<0.2$. Then bring to $20 \%$ ethanol by adding 15 liters of $53.3 \%$ ethanol, keeping the temperature as low as possible until $-5^{\circ} \mathrm{C}$. is reached. This suspension should stand at $-5^{0} \mathrm{C}$. with slow stirring for several hours before centrifuging. Centrifuge at a tate of about 30 liters/hour.

"Precipitate $I I+I I I W$ consists of practically all of the $y$-globulins, isoagglutinins and prothrombin originally present in the Fraction II + III. It contains very little 
cholesterol or carotenoid pigment. From a pool of normal plasma, it should represent about $60 \%$ of the original II + III paste, and will contain $50-55 \%$ of $\gamma$-globulin by electrophoresis at $\mathrm{p}_{\mathbf{H}}$ 8.6." (Description prepared by the Plasma Fractionation Laboratory, Harvard Medical School, dated July 27, 1945.)

Separation of Prothrombin, Isoagglutinins, Plasminogen, and $\gamma$-Globuliqns. Method 9.

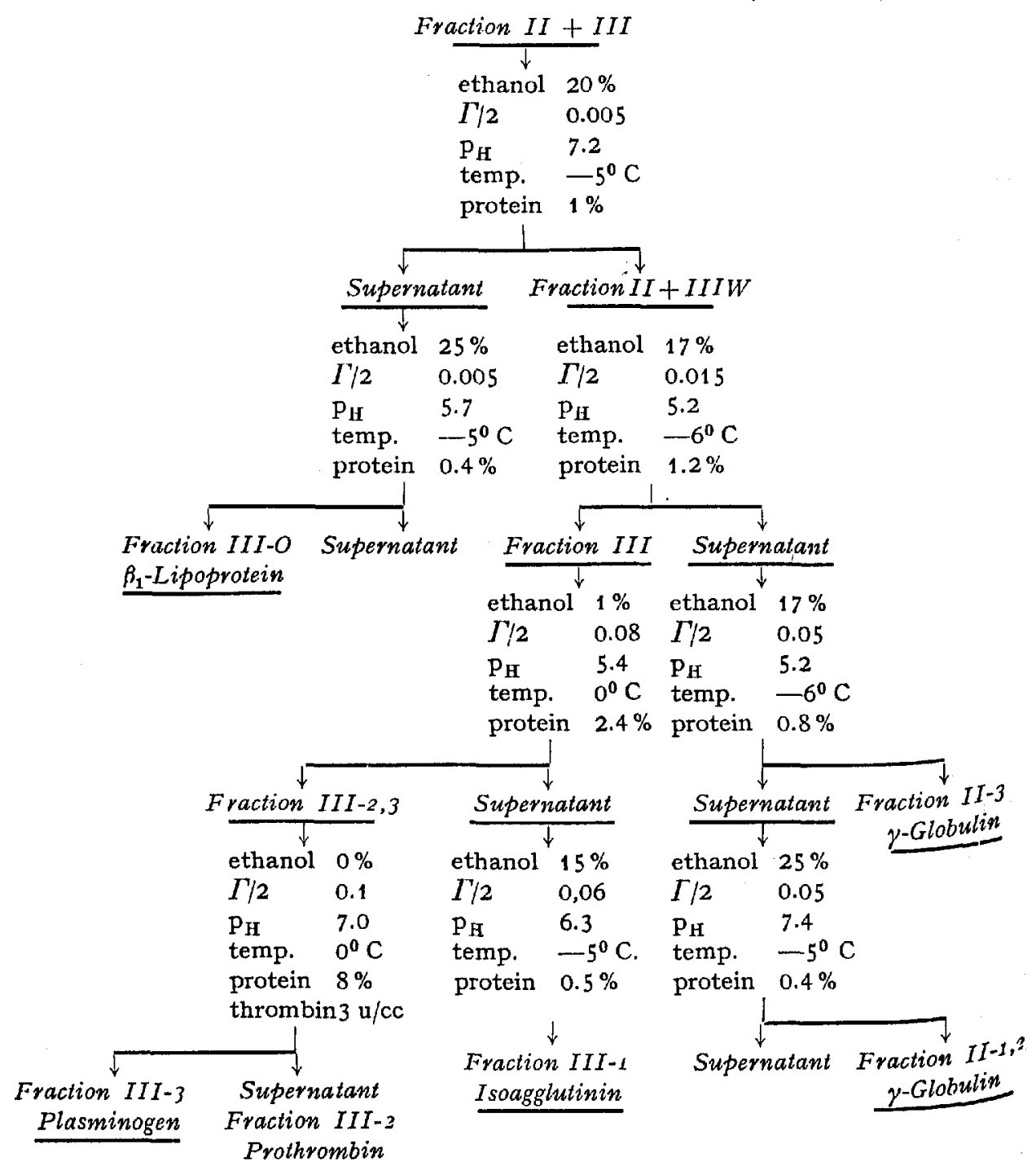

Fig. 1. Separation of Prothrombin, Isoagglutinins, Plasminogen, and $\boldsymbol{\gamma}$-Globulius. From L. E. STRONG $(139)$.

Fraction III-2,3 - the euglobulin fraction with minimum solubility near $\mathrm{P}_{\mathrm{H}} 5.2$ - contains prothrombin, the midpiece (component $\mathrm{C}_{1}^{\prime}$ ) of complement, and plasminogen; the precursor of the proteolytic enzyme of plasma.

Prothrombin and Thrombin. Prothrombin is somewhat unstable at such an acid $p_{H}$ as 5.2, and this fraction therefore should be promptly redissolved 
at higher salt concentration and at $a p_{r I}$ of 6 or higher. Human prothrombin, as obtained in this fraction, has been generally converted to thrombin by the action of calcium ions and placental thromboplastin (53); the conversion is very slow at $p_{H}$ values acid to 6 , but goes rapidly above 6.3 at room temperature (56). The resulting thrombin is much more stable than the prothrombin from which it is formed, although it loses most of its activity within a few days on standing in solution. When dried from the frozen state, it is very stable and retains its full activity for a period of years (56).

The human prothrombin preparations so obtained are still very impure, containing ordinarily 20 or 30 prothrombin units per mg. of protein ${ }^{1}$ : As a result of a long period of research, SEEGERS and his associates $(132,133)$ have recently obtained bovine prothrombin in what appears to be pure form. Their method involves an initial precipitation of diluted beef plasma with acid at $\mathrm{p}_{\mathrm{H}}$ 5.1. This is followed by adsorption on $\mathrm{Mg}(\mathrm{OH})_{2}$ suspension. The adsorbed prothrombin is eluted by decomposing the $\mathrm{Mg}(\mathrm{OH})_{2}$ under pressure with $\mathrm{CO}_{2}$. The eluate is fractionated with ammonium sulfate in the cold, and finally the prothrombin is separated by isoelectric precipitation. The final product contains approximately 1500 prothrobin units per $\mathrm{mg}$. dry weight. It behaves as a chemical individual by the solubility test. [For the principles involved in the solubility determination, see Northrop (114) and HERrIotT (79). I It contains $14.5 \% \mathrm{~N}, 4.3 \%$ carbohydrate (as judged by the orcinol test), and is present in a concentration of approximately $200 \mathrm{mg}$./ $\mathrm{l}$. in bovine plasma.

Highly active thrombin has also been prepared by Milstone (106), by a procedure differing considerably from that of SELGERS.

The Proteolytic Enzyme System of Plasma (Plasmin and Plasminogen). It has long been known that fibrin clots commonly dissolve after a few hours or days, even in the complete absence of bacterial contamination. It was inferred that this lytic action was due to an enzyme.

In 1903, Delezenne and Pozerski (43) reported that serum became proteolytic when shaken with chloroform, a phenomenon which has been studied in detail by a series of later investigators [see, for instance, TAGNON

\footnotetext{
'The prothrombin unit was originally defined by SEEGERS, SMITH, WARNER, and

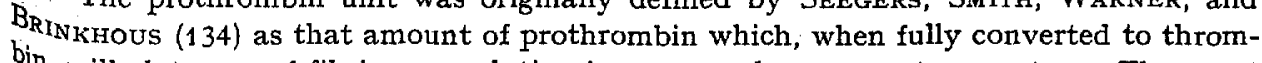
bin, will clot $1 \mathrm{cc}$. of fibrinogen solution in 15 seconds at room temperature. The exact clotting time obtained" can vary considerably with the fibrinogen preparation used and with conditions such as $\mathrm{P}_{\mathrm{H}}$ and salt concentration. In the more recent work in this laboratory, a given preparation of thrombin was taken as a standard, and unknown preparations were assessed with a given fibrinogen preparation, using serial dilutions of both standard and unknown thrombin. The activity of the known preparations was thus directly given by determining the dilution which gave the same clotting time as one unit of the standard. Such standard thrombin preparations are now distributed by the National Institutes of Health, Bethesda, Maryland. I have recently discussed this problem in more detail in another review (51).
} 
(147)]. This later work indicated that the proteolytic activity induced by chloroform was concentrated in a euglobulin fraction with a minimum solubility near $\mathrm{p}_{\mathrm{H}} 5.2(148,85)$.

In the mean time, the study of fibrinolytic activity had been carried on from what at first appeared to be a totally different point of view. It was found by Tillet and Garner $(150,69)$ that a very active lytic agent which rapidly dissolved fibrin clots, especially from human plasma, could be extracted from cultures of hemolytic streptococci. The lytic action on human fibrin clots was much more powerful than on clots from most animal bloods. A few years later, MiLsTone (105) showed that the substance from streptococci did not act on highly purified human fibrinogen; it was necessary to add also a certain euglobulin fraction from human plasma which had a solubility minimum near $\mathrm{p}_{\mathrm{H}}$ 5.2. The work of CHRISTENSEN (24) and of CHRISTENSEN and MACLEOD (26) further clarified the nature of the reaction. They showed by a series of careful and critical experiments that the streptococcal factor served as an activator for an enzyme precursor present in the euglobulin fraction of normal human plasma; they therefore termed the activator "streptokinase", to indicate its origin and its functional relationship to such other activators as enterokinase. Streptokinase was found to convert the enzyme precursor of plasma into the active enzyme with great rapidity. This enzyme was found to act not only on fibrin and fibrinogen, but also on gelatin, casein, and other proteins. It was therefore a true proteolytic enzyme. Its action could be inhibited quite markedly by the crystalline inhibitor which NorThrop and KunITz (114) had prepared and shown to have a high inhibitory action on crystalline trypsin. The form of the inbibition curves was quite different, however, for crystalline trypsin and for the plasma enzyme, indicating their lack of identity. Christensen and Macleod named the plasma enzyme "plasmin" and its inactive precursor "plasminogen", and their terminology will be followed here'. They also prepared activated enzyme

1 The terminology in this field has unfortunately been extremely varied. FERGUSON (60) has termed the enzyme "serum tryptase" to indicate its general relationship to trypsin as regards $\mathrm{p}_{\mathrm{H}}$ optimum. However, recent tests by J. S. FRUTON (unpublished) on material prepared at the Harvard Pilot Plant by RICHERT, MILLER, and EDSAIL indicate that the type of peptide linkage split by plasmin is quite different from that split by trypsin. This, in conjunction with the evidence of CHRISTENSEN, cited above, appears to remove the justification for denoting plasmin by a name suggesting a relationship to trypsin. The name "fibrinolysin" has also been used for the plasma enzyme, as for instance by the present author in a previous article (53). This terminology ap" pears undesirable, since the enzyme is not specific for fibrin, but is a general proteolytic enzyme capable of splitting a certain type of peptide linkage. Moreover, the factor here denoted as streptolkinase was referred to in earlier papers as "streptococcal fibrinolysin", the name here denoting an entirely different substance from the plasma enzyme.

In 1948 this question of terminology was considered by a committee at a meeting on "Blood Clotting and Allied Problems" sponsored by the Josiah Macy, Jr. Foundation" in February, 1948. This committee was unable to reach unanimous agerement and the 
from the euglobulin fraction of plasma by chloroform treatment without streptokinase. By every test which they applied, the enzyme produced by the action of chloroform behaved like that produced by streptokinase activation.

In the low temperature ethanol fractionation at the Harvard Pilot Plant it was found that plasminogen was highly concentrated in Fraction III-2,3. It was desired to separate it as completely as possible from the prothrombin with which it was closely associated, and which was very similar in its solubility characteristics. In D. A. RicherTs method a considerable degree of concentration was achieved by making use of the fact that most of the fibrinogen, not already precipitated in Fraction I, was concentrated in Fraction III-2,3. On the addition of a moderate amount of thrombin, a fibrin clot was formed which was then centrifuged off, and was found to carry a great deal of plasminogen activity adsorbed on the fibrin clot. On standing in the cold for a day or two, or in a few hours at room temperature, the clot lysed spontaneously, owing to the action of the plasmin which was formed from the plasminogen under these conditions. The resulting fraction was designated as III-3. On holding the preparation at $0^{0}$ for two or three weeks, a slowly progressive activation occurred without the addition of chloroform, streptokinase, or any other activator. The final concentration of plasmin obtained in this way was about one-third of the maximum obtainable on complete activation with streptokinase. Chloroform treatment of Fraction III-3 did not give any increase in the rate or in the firal amount of activation, as compared with the control sample without added activator. This is perhaps explainable by the fact that the lipids present in Fraction II + III were previously separated in Fraction III-0. The function of the chloroform in whole plasma or crude plasma fractions may well be due to its extraction of fat soluble inhibitors which normally prevent the spontaneous conversion of plasminogen to plasmin ${ }^{1}$.

Even the most active enzyme preparations yet obtained are still very. impure. Further purification will be important, both in making highly active

recommendation was made that either the term "fibrinolysin" or "plasmin" might be used to denote the active enzyme and "profibrinolysin" or "plasminogen" to denote its precursor. It was also recommended that, whichever term was used, the alternative term should be inserted in parenthesis after it at the first point in the paper at which these terms were used (see the Proceedings of this conference, published by the Josiah Macy, Jr. Foundation, 565 Park Avenue, New York, N.Y., page 38).

1 This conclusion has been strengthened by later work of CHRISTEnsen (25) who has shown that chloroform apparently acts on serum or plasma by removing the inhibitor of the enzyme which is present in serum. He also found that chloroform treatment of serum caused some destraction of plasminogen, and suggested that the spontaneous activation of plasminogen which occurs following removal of inhibitor might be autocatalytic in nature. He also observed, in agreement with findings from this laboratory, that active plasmin in solution appears to destroy both plasmin and plasminogen activity. 
preparations available for possible clinical uses, and in studying the role of the enzyme in the blood coagulation mechanism. Several recent authors, notably FERguson (59) and TAGNON (147) have stressed its possible importance in the latter connection. More recently SEEgERS and Loomis (131) have reported that plasmin (fibrinolysin) when free of thrombin and prothrombin does not activate prothrombin or clot oxalated plasma or fibrinogen solutions. However, it does inactivale prothrombin at a fairly rapid rate, although thrombin is not inactivated by it.

Isoagglutinin Preparations: Anti-A, Anti-B, and Anti-Rh. The anti-A and anti-B isoagglutinins which react with the specific $A$ and $B$ substances of red cells are concentrated in Fraction III-1, which consists of euglobulins with minimum solubility near $\mathrm{p}_{\mathrm{H}} 6.3(122,115,116)$. In order to obtain type specific preparations, it is of course necessary that the pooled plasma used for processing be taken only from blood of the correct type. In considering the choice of bloods for obtaining active fractions for typing, certain elementary points regarding the nature of blood groups and their frequency in a typical American population must be borne in mind (Table III).

Table III.

\begin{tabular}{c|c|c|c}
\hline Blood Group & $\begin{array}{c}\text { Agglutinogen } \\
\text { Present in Cells }\end{array}$ & $\begin{array}{c}\text { Agglutinins in } \\
\text { Plasma }\end{array}$ & $\begin{array}{c}\text { Per Cent of Population } \\
\text { in Group (in U.S.A.) }\end{array}$ \\
\hline & $\ldots$ & anti-A, anti-B & 45 \\
O & $\ldots$ & anti-B & 41 \\
A & B & anti-A & 10 \\
AB & A and B & $\ldots$ & 4
\end{tabular}

Percentage figures from Wiener "Blood Groups and Transfusion"; data of SNYDER.

It can be seen from the table that the preparation of anti-B isoagglutinins from donors of type $A$ should be a relatively simple and straight-forward problem, granted a suitable method of fractionation. Donors of type A make up more than $40 \%$ of the population, and the supplies from this source are ample. To obtain adequate quantities of anti-A isoagglutinins is a more difficult problem. It is of course true that these can be prepared by $\mathrm{frac}^{-}$ tionation of pooled plasmas from donors of type B. However, such donors make up only $10 \%$ of the population. This raises a serious difficulty, since equal amounts of anti-A and anti-B agglutinins are required as reagents for typing. Moreover, the anti-A agglutinins from type $B$ plasma are often deficient in their reactions with certain rare sub-types of cells, notably with cells of type $A_{2} B$. The problem of obtaining a large yield of anti-A isoagglutinins was ingeniously solved by MELiN (100), by combining bloods of type $O$ and type $B$ as they were obtained at a large blood donor center. Plasma from type $O$ blood contains both anti- $A$ and anti-B agglutinins; and moreover 
it is more active than type $B$ plasma in its reactivity with cells containing the $A_{2}$-agglutinogen (cells of type $A_{2}$ and $A_{2} B$ ). The $B$ cells, on mixture with $O$ blood, absorb the anti-B activity almost completely, leaving the anti-A activity in the plasma of the mixed bloods. Cells and plasma are then separated; and the plasma is fractionated in the usual manner, the anti-A agglutinins being concentrated in Fraction III-1. By this means, the plasma available for the preparation of anti-B isoagglutinins from a pool of a typical American population is equal to, or slightly greater than, the amount of anti-B agglutinin available from donors of type A. Furthermore, the anti-A isoagglutinins, thus prepared from combined $\mathrm{O}$ and $\mathrm{B}$ blood, are somewhat more active, especially against the rare sub-groups $A_{2}$ and $A_{2} B$, than are the isoagglutinins taken from type $B$ donors alone. For a detailed description of the procedure, MELINs article should be consulted; it is to be emphasized, however, that a very careful testing of all the individual bloods used in preparing the $\mathrm{O}+\mathrm{B}$ pool is essential. A single sample of type A blood, even in a very large pool of $O+B$ blood, is enough to reduce the anti-A activity of the resulting isoagglutinin fraction very markedly indeed.

The assay of isoagglutinin activity proved to raise considerable difficulties, for the techniques employed in different laboratories were so different in detail that the results were not quantitatively comparable, and the red cells used to observe the agglutination reaction inevitably varied somewhat from one individual donor to another. To eliminate these complications, Reference Standard preparations of anti-A and anti-B agglutinins were made up from certain preparations of Fraction III-1, and distributed to all investigators testing new preparations. By assay of the activity of a new preparation against the reference standard, studying both at a series of dilutions, the relative activity of different preparations could be reliably estimated (42). Just as Fraction III-2,3 consists of a few per cent of prothrombin, with a large amount of inert protein, so Fraction III-1 consists only of about one Per cent of isoagglutinins ${ }^{1}$, the rest of the protein in this fraction not being directly involved in the reaction with A and B substances. Thus the proPerties of pure isoagglutinins cannot be deduced from those of the total Protein in Fraction III-1; but this fact does not impair the value of these Preparations as blood typing reagents of high titer and avidity.

Anti-Rh Isoagglutinins. Although they were discovered only as recently as 1940 by LANDSTEINER and WIENER, the Rh factors are now recognized as being comparable in importance with the $\mathrm{A}$ and $\mathrm{B}$ factors, of which they tre genetically independent. Anti-Rh isoagglutinins are not found in normal $\mathrm{Plasma}_{\mathrm{a}}$ but are produced in Rh-negative individuals exposed to Rh-positive cells, either by transfusion, or by passage of minute numbers of cells (or breakdown products containing the Rh factor) from an Rh-positive fetus to

${ }^{1}$ Personal communication from Dr. E. A. Kabat. 
an Rh-negative mother, across the placental membrane. The grave consequences which may ensue, in the form of the disease erythroblastosis fetalis and in other respects, have been discussed in many places.

What concerns us here is the preparation of typing reagents. Anti - Rh agglutinins are present in only a very small fraction of the general population; they must be obtained from sensitized Rh-negative donors, specially selected ${ }^{2}$. On fractionation, these agglutinins, like anti-A and anti-B, are found in Fraction III-1. Fractionation here has proved particularly useful, since most of the whole sera, as collected, are too weak to use as such for typing purposes, but are effective when the agglutinins are concentrated in Fraction III-1.

The $\gamma$-Globulins of Human Plasma. The $\gamma$-globulin fractions II-1,2 and II-3 obtained by the procedures outlined on pp. $329-30$ can readily be obtained as preparations giving practically only a single boundary in electrophoretic measurements. Preparations containing $98 \% \gamma$-globulin or better are readily obtained. However, this boundary; as shown particularly by the work of ALBERTY (2) is far broader than would be expected for a single component. This spreading of the boundary progresses with time; moreover, the spreading is largely reversible on reversing the direction of the current. This shows that many different components with different isoelectric points are present in the preparation. ALBERTY has calculated a heterogeneity coefficient which gives a measure of the breadth of this distribution. A small but significant fraction of the $\gamma$-globulin molecules in the preparation have isoelectric points at least one $\mathrm{p}_{\mathrm{H}}$ unit more acid and more alkaline than the mean isoelectric point of the preparation.

There are also other indications of heterogeneity. ONCLEYs ultracentrifugal studies (117) [see also Williams et al., (153)] have shown that only $75-85 \%$ of the protein in this fraction sediments with the value $s_{20}=7 \mathrm{~S}$; the remainder consists of one or more faster moving components, with $s_{20}=10 \mathrm{~S}$ approximately. Furthermore, this fraction has been shown by repeated tests, both immunological and clinical, to contain a large number of antibodies. Those determined by laboratory procedures include antibodies to diphtheria, influenza, mumps, whooping cough, scarlet fever, poliomyelitis, lymphocytic choriomeningitis, certain streptococci, vaccinia, and typhoid ${ }^{3}$. The evidence,

1 For a review of the Rh factor, see for instance Boyn (14); also the papers by $\operatorname{LIVIN} 46$ and by WiEner and Sonn, in "Annals of the New York Academy of Sciences", vol $4^{6}$ (1946).

2. The presence of "blocking" antibodies in many such anti-Rh sera (48) further complicates the problem of observing the agglutination reactions. Agglutination of $\mathrm{Rh}^{\mathrm{h}}$ positive cells by such sera is greatly improved by the addition of whole plasma or various plasma.fractions. Serum albumin, because of its ready availability in large quantities today, has been found particularly useful as a reagent to aid in Rh typing determination ${ }^{5}$ (20).

3 The typhoid $\mathrm{H}$ agglutinin is found in Fractions II-1,2 and II-3; but the typhoid 0 agglutinin is found predominantly in Fraction III-1. 
derived from studies by many workers, is summarized by ENDERs (57) in a comprehensive paper.

Moreover extensive clinical trials have shown the great utility of such preparations in producing temporary passive immunization to measles (118, 137), and to infectious hepatitis $(138,70,76)$, and have thereby demonstrated that antibodies to both these diseases are present in the $\gamma$-globulin fraction of human blood. Unquestionably many other antibodies are present also in this fraction and have not yet been detected simply because they have not been tested for ${ }^{1}$.

The $\gamma$-globulin of Fraction II is readily prepared in aqueous solutions containing $16 \%$ or more of protein. The $\gamma$-globulin and antibody content of such solutions, per unit volume, are approximately 25 times as great as in the plasma used as starting material. By fractionating plasma derived from donors convalescent from a particular disease, the specific antibody content of the original plasma is much irreased; and the concentrated Fraction II from such plasmas may become a verful agent in the treatment of certain diseases. Studies of this sort, using nors convalescent from mumps, from scarlet fever, and from other diseases L.lve already begun.

Studies have been made in the Wisconsin laboratories of the enzyme digestion of human $\gamma$-globulin. BRIDGMAN (19) found that pepsin digestion at $\mathrm{p}_{\mathrm{H}} 3.5$ led chiefly to the production of molecules of approximately half the original size, $s_{20}$ falling from 7 to $6 \mathrm{~S}$. The optimum conditions for halfmolecule production involved digestion for three days, in the cold, with at least 0.05 hemoglobin units of pepsin per g. globulin. Further digestion led to the production of still smaller molecules and eventually of dialyzable fragments. On immunological assay of the preparations of half-molecules, it was found that most of the antibody activities were present in undiminished potency, although the typhoid " 0 " agglutinin was destroyed.

Digestion by papain or bromelin [PetErmann (121)], on the other hand, led to the formation of quarter-molecules $\left(s_{20}=4.1 \mathrm{~S}\right)$ with only a small increase in non-protein nitrogen. Electrophoretically the digestion products Were very inhomogeneous, giving a series of different components, in sharp contrast to the pepsin digestion products, which were homogeneous in this respect and practically identical in mobility with the undigested globulin. The quarter-molecules still possessed some antibody activity, although considerably less, with respect to most of the antibodies tested, than was present in the original globulin.

\footnotetext{
1 All the earlier studies were made with Fraction II preparations essentially equivalent to what is now denoted as II-1,2. Fraction II-3 represents additional $\gamma$-globulin, not recovered in the earlier procedures. Its content of nearly all antibodies (including measles antibody) is virtually identical with that of II-1,2; at present no opportunity has arisen to test its effectiveness in infectious hepatitis. It seems probable that for clinical use, the two subfractions can be combined into a total Fraction ( $\gamma$-globulin). 
Deutsch, Petermann, and Williams (47) developed a combined pepsin digestion and fractionation system to recover half-size $\gamma$-globulin antibodies from an initial fraction containing $\beta$ - and $\gamma$-globulins ${ }^{1}$. The half-size antibodies give less viscous solutions, and diffuse more rapidly, than the original molecules, and these modified properties may be valuable for clinical use.

Deutsch, Gosting, Alberty, and Williams (46) found that the less soiuble fraction of the $\gamma$-globulin was best separated from $\beta$-globulin at $p_{H} 5.1$ and at low ionic strength (near 0.01). Under these conditions, at 17 per cent ethanol and $-6^{0}$, the $\gamma$-globulin remains in solution while the $\beta$-globulin is precipitated. This observation represented one of the important steps leading to the separation of Fraction II-3 in method 9.

Separation of a globulin with electrophoretic mobility slightly greater than that of ordinary $\gamma$-globulin has been reported by DEUTSCH, ALBERTY, and Gosting (44). They denote this new fraction as $\gamma_{1}$-globulin (other authors have denoted it as $\beta_{2}$ ) and report on detail methods for its separation from the bulk of the $\gamma$-globulin fraction (which they denote as $\gamma_{2}$-globulin).

Separation by the method of electrophoretic convection [NIELSEN and KIRKWOOD (113)] seems to have a promising future in the further study of the $\gamma$-globulins as well as many other protein fractions. CANN, BROWN, and KIRKWOOD (20a), have reported a successful subfractionation into three subfractions with different mean isoelectric points, and the prospects appear promising for further successful subfractionations. A combination of the electrophoretic method with further chemical subfractionation may also yield important results.

\section{Components of Fraction IV $-4^{2}$.}

Fraction IV-4, separated just before the albumins, consists largely of $\alpha$ - and $\beta$-globulins, together with a small amount of albumin. It comprises slightly more than $7 \%$ of the plasma proteins. During the subfractionation of this complex fraction, several components have been concentrated (144); these include plasma choline esterase, a metal-combining globulin, and carbohydrate-rich $\alpha_{2}$-globulins.

Plasma choline esterase ${ }^{3}$ has been concentrated into the subfraction called IV-6 (144), from which it has been further purified (142).

1 This fraction was denoted as III-1 in an earlier fractionation method $3 \mathrm{C}$ (sec ONCLEY et all (116)]. The $\gamma$-globulin present in this fraction was later separated in Fraction II-3 in method 9.

${ }^{2}$ I am indebted to Dr. Dougr.As M. Surgenor for Section 6 of this review.

3 This enzyme has been called serum esterase or pseudocholine esterase. It differs in substrate specificity and in its interaction with various cholinergic substances from the choline esterase of nervous tissue or that associated with the stroma of the red cell. Concerning its specificity, see Mendel and Ru,pNey (103). Mendel, MundeII, and RUDNEY (102); concerning its interaction with various inhibitors, see ZELLER and Bissegger (155) and Goldstein (71). 
Carbohydrate-rich $\alpha_{2}$-globulins. Fraction IV-6 not only contains choline esterase, but also is a concentrated source of $\alpha_{2}$-globulins, which are rich in bound carbohydrate. These proteins were pseudoglobulins with minimum solubility near $p_{H}$ 4.5. Although homogeneous by electrophoresis at $p_{\text {. }}$ 8.6, they usually showed several components in the ultracentrifuge. These proteins have not been purified, nor has their physiological function been defined ${ }^{1}$. A new method of plasma fractionation, now being developed, is yielding more satisfactory preparations of these and of other labile components of plasma (33).

In addition to these pseudoglobulin components, a purified mucoprotein has been obtained (144), isoelectric near $\mathrm{p}_{\mathrm{H}} 5.0$, containing $4.3 \%$ carbohydrate (as galactose and mannose) and $2.8 \%$ glucoseamine. Its ultracentrifugal behavior suggested a highly assymetrical molecule. The mucoprotein did not precipitate, on boiling a $2 \%$ solution for four hours, but was precipitated from $7 \%$ trichlor-acetic acid. This protein had a marked accelerating effect on the rate of sedimentation of human érythrocytes, which, however, was not as pronounced as the effect produced by fibrinogen, the principal component of normal plasma affecting erythrocyte sedimentation rates $(58,72)$.

An $\alpha_{2}$-globulin which separated with the metal combining globulin into Fraction IV-7 has been distinguished from the $\alpha_{2}$-globulins of Fraction IV-6 by its ability to bind bilirubin, a property which was not shared by the proteins in Fraction IV-6 (99).

$\beta_{1}$-Metal-Combining globulin. It was early recognized by $\operatorname{BARKAN}(5,6)$ that serum contains a small amount of iron which is readly split off on acidification. Later it was found that this iron-binding power was associated with the globulin fraction of blood (7). The biological assay for this component of plasma, based on the iron requirement of certain bacteria (129), and the Observation that the metalprotein complex was colored (128), aided materially in its separation into Fraction IV-7 $(144,143)$, and its crystallization from ethanol-water mixtures (91). In Fraction IV-7, the metalbinding protein is $75 \%$ pure, and this fraction has been used for intravenous injection in $\operatorname{man}(123,22)$.

The metal-combining globulin crystallized from human plasma is a $\beta_{\mathbf{1}^{-}}$ Psendoglobulin, isoelectric near $\mathrm{p}_{\mathrm{H}}$ 5.9. It is otherwise entirely unlike the other $\beta_{1}$-globulins of plasma, such as the $\beta_{1}$-lipoprotein or the lipid-free $\beta_{1}$-globulin which separated into Fraction II + III (116). The crystallized protein was free of lipid, contained $14.7 \%$ nitrogen and $1.8 \%$ carbohydrate. The molecular weight in the ultracentrifuge was $90,000\left(s_{20, w}=5.0\right)(117)$ While the minimum molecular weight calculated from the iron content of

\footnotetext{
${ }^{2}$ Hypertensinogen is present in high concentration in the solution remaining after Precipitation of Fraction IV-1. "Precipitation of Fraction IV-4 ... led to the destruction of hypertensinogen and presumably of other labile components of the fraction without, bowever, destroying gross molecular structure." (39). 
the iron-protein complex was 45,000 . The protein is thus capable of binding 2 atoms of iron per molecule $(143,91)$.

The broad absorption band of the protein-iron complex, measured against a metal-free protein blank, had its maximum near $465 \mathrm{~m} \mu$, with extinction coefficient $\mathrm{E}_{1 \mathrm{~cm}}^{1 \%}=0.570$. The reaction with iron was dependent on $\mathrm{p}_{\mathrm{H}}$; at $\mathrm{p}_{\mathrm{H}}$ below 5 the iron could be dialyzed from the colorless solution, while above $p_{H} 7$ the color was maximal, and the protein was capable of binding $1.25 \%$ of iron per milligram. Either ferrous or ferric iron reacted, although the latter reacted much more slowly, due to the lower solubility and more rapid hydrolysis of ferric salts at neutral $\mathrm{p}_{\mathrm{H}}$. Magnetic susceptibility measurements by Dr. LEONOR MICHAEIIS (104) indicated that regardless of whether the iron added was in the ferrous or ferric state, the iron in the complex was in the ferric state, and that the complex was ionic, not covalent. It was therefore evident that ferrous iron was oxidized prior to or during the formation of the complex. Carbon dioxide is essential for the formation of the metal-protein complex (130). FIALA and BURK (66) have pointed out the similarity in the absorption maxima and extinction coefficient (based on iron) of the iron-protein complex to those of the iron-aspergillic acid and ironhydroxyl amine complexes, as well as the iron complexes of other simpler model compounds, such as N-hydroxy, 4-methylpyridone-2, all of which contain the cyclic hydroxamic acid grouping shown by DUTCHER to be responsible for the binding of iron by aspergillic acid (50). From their observations, FIALA and Burk postulate that the group on the protein which is involved in the binding of iron might be represented as

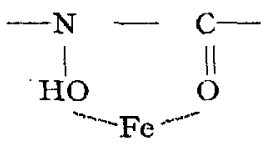

The metal-combining globulin ${ }^{1}$ has been so named because of its ability to interact in vitro, with copper, as well as iron. The interaction with copper results in the formation of a complex with an absorption maximum near $435 \mathrm{~m} \mu$ with $\mathrm{E}_{1 \mathrm{~cm}}^{1 \%}=0.45$. Maximum binding of copper occurred alkaline to $\mathrm{p}_{\mathrm{H}}$ 8. Iron displaced copper from the compex with a simultaneous change in color. No conditions were observed where copper would displace iron from the iron protein complex.

An iron-binding protein has been isolated from swine serum (92). Obtained as the iron-protein complex, the molecular weight was found to be 88,000 and unlike the protein from human plasma, the isoelectric point was found to be near $\mathrm{p}_{\mathrm{H}}$ 4.4. This protein also combined with copper $(83)$.

\footnotetext{
1 This protein has been called siderophilin by SCHADE (130) and transferrin by Holmberg and LauRELI (83).
} 


\section{Properties and Crystallization of Serum Albumin.}

The serum albumins represent the largest single fraction of the plasma proteins. The most careful and critical electrophoretic studies, such as those of Perrmann and Kaufman (120) and of Armstrong, Budika, and MorRISON (3), indicate that the albumins make up approximately $53 \%$ of the total plasma proteins. As shown by the theoretical and experimental investigations of DoLE (49) and Svensson (146), the direct measurements of the areas under the electrophoretic peaks in an ordinary experiment do not give the true values for the relative concentrations of the different components. As Svensson has stated (146, p. 26), "The refractive index increment given by the leading ion is enlarged by slower surrounding ions of the same charge; it is diminished by faster ions of the same charge and by ions of the opposite charge." According to this rule, the fast moving albumin peak always appears relatively too large in an electrophoretic diagram of the plasma proteins, and the slow $\gamma$-globulin peak appears too small. To obtain the true value for the relative concentration of the electrophoretic components, measurements should be carried out at several different ionic strengths and several different protein concentrations. The percentage of the total area under the peak corresponding to any component in the diagram may then be plotted against the ratio of protein concentration to ionic strength. Extrapolation of the measurements to a zero value of this ratio should give a reliable estimate of the amount of the component present ${ }^{1}$. The figure of approximately $53 \%$ albumin in human plasma was derived essentially on this basis.

Fraction V, as precipitated after the separation of Fraction IV-4, contains 85-90 per cent of the total albumin of plasma [see CoHn, Strong, Hughes, et al (39), especially their Table IX]. Of the protein in the fraction, approximately 95 per cent is albumin; of the remainder, approximately 3 to 4 per cent is $\gamma$-globulin and approximately $0.5 \%$ is $\beta$-globulin. If the albumin is intended for clinical use, only one further step in purification has generally been employed. The precipitated Fraction $\mathrm{V}$ is redissolved in 6 volumes of water at $0^{0}$, and ethanol is added over a period of about two hours to a final concentration of approximately $10 \%$, the temperature being reduced to between -2 and $-3^{\circ}$. The resulting turbid solution is stirred gently but thoroughly for about two hours, then clarified by filtration. Albumin is then precipitated from the filtrate by raising the ethanol concentration to $40 \%$,

\footnotetext{
1 It should be remembered, of course, that the concentration so estimated is expressed in terms of the relative refractive index increments of the various components and not in terms of their weight concentrations. ARMstrong BUdKa Morrison, and $\mathrm{H}_{\text {ASSON }}$ (4) have determined the refractive index increments of a number of the major fractions of plasma. Most of these fractions give nearly identical refractive increments - about $1.87 \times 10^{-4}(\mathrm{~g} . / \text { liter })^{-1}$ for light of wave length $5893 \AA$ - but the proteins containing a significant amount of lipid or carbohydrate give lower values. The lowest value observed was for the $\beta_{1}$-lipoprotein - namely, $1.70 \times 10^{-4}$ (g./liter) ${ }^{-1}$.
} 
lowering the temperature to $-5^{\circ}$, and, in order to minimize absorption of acetic acid by the precipitate, raising the $p_{H}$ to 5.2 with sodium bicarbonate. The precipitated albumin is centrifuged off and dried from the frozen state at as low a temperature as is practical. For clinical use it has been redissolved in a sterile solution at a concentration of $25 \%$. By the addition of suitable stabilizing agents, these albumin solutions can be made very stable to heat. Fatty acid anions are remarkably effective stabilizers, as shown by the work of LUCK and his associates (15). In the presence of $0.04 M$ sodium caprylate, for example, serum albumin may be heated for 10 or 15 hours or even more at $60^{\circ}$ without showing a significant increase in turbidity or any other sign of denaturation. The sodium salt of acetyltryptophane has also proved to be a very effective stabilizing agent, as shown by the studies of Scatchard, Strong, Hughes, Ashworth, and Sparrow (127), and this substance at a concentration of $0.04 M$ has been employed in all the serum albumin preparations put up for clinical use in recent years. In this medium the albumin solution may be heated for 10 hours at $60^{\circ}$ without significantly altering its chemical stability or its clinical safety or usefulness. This heat treatment is effective, not only in destroying any bacteria that might have passed the sterilizing filter, but also in destroying viruses, such as that of infectious jaundice, which cannot be removed by filtration. Thus it has been possible to eliminate the mercurial preservative which had earlier been required in albumin preparations intended for clinical use and at the same time to obtain added security against the possibility of virus infections resulting from albumin injection.

This stabilizing action on serum albumin of certain organic anions is closely associated with the remarkable tendency of albumin to bind many of these substances more or less tightly. The recognition of the extent and the importance of such phenomena is largely due to the classic work of BENNHoLD $(8,9)$; and many recent studies have emphasized and extended the significance of BENNHolds: conclusions. Thus, for example, DAvis (40) has shown that sulfanilimide and other sulfa drugs are bound largely to albumin in plasma and do not appear to interact with the globulins; and MARTIN (99) has shown that one molecule of albumin binds 2 or 3 molecules of bilirubin. SCATCHARD, BATCHELDER, and BROWN (125) concluded from osmotic pressure studies that albumin combines with chloride ions (approximately 6 per albumin molecule) even when the protein carries a negative net charge ${ }^{1}$. Extensive quantitative studies of the binding of a number of dyes by serum albumin have recently been carried out by KLOTz and his associates $(88,89,90)$. For a review of other recent work in this area, see also EDSALL (52).

1 For recent accurate measurements of binding of chloride and Thiocyanate by albumin, see G. Scatchard, I. H. Scheinblerg and S. H. Armstrong, Jr. J. amer. chem. Soc. 72, 535, 540 (1950). 


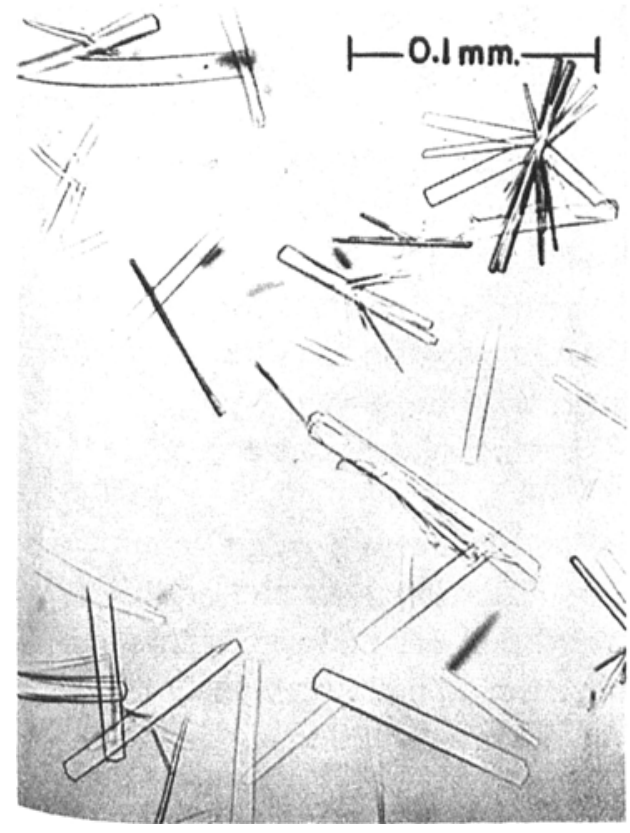

a

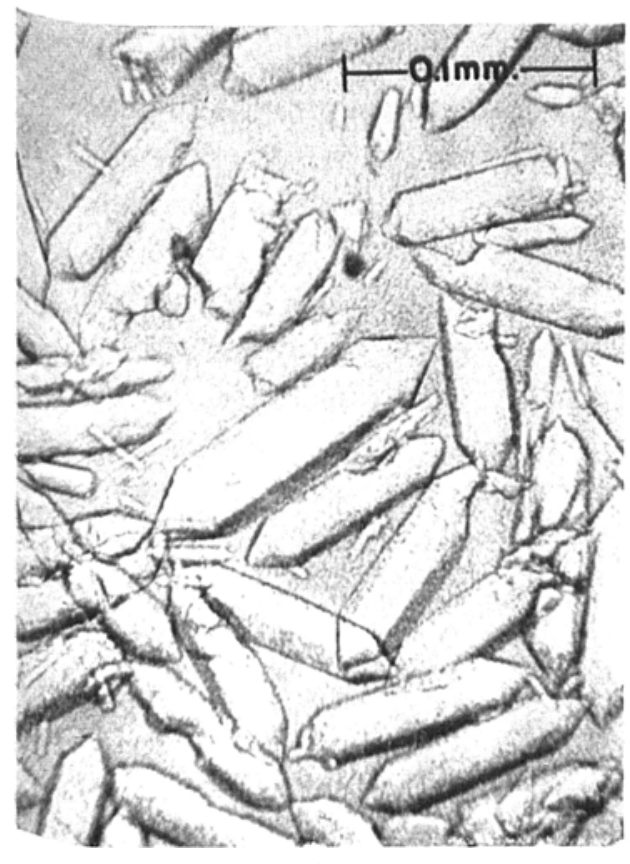

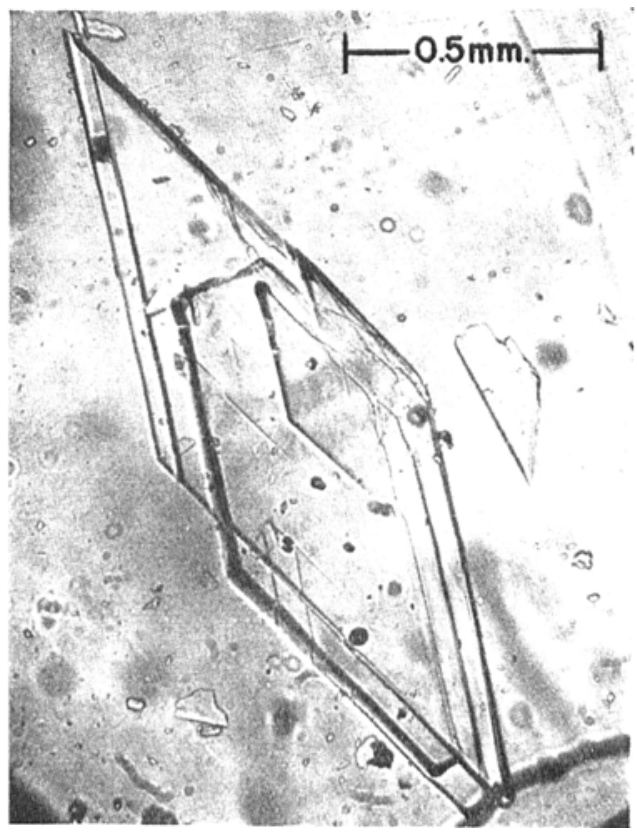

b

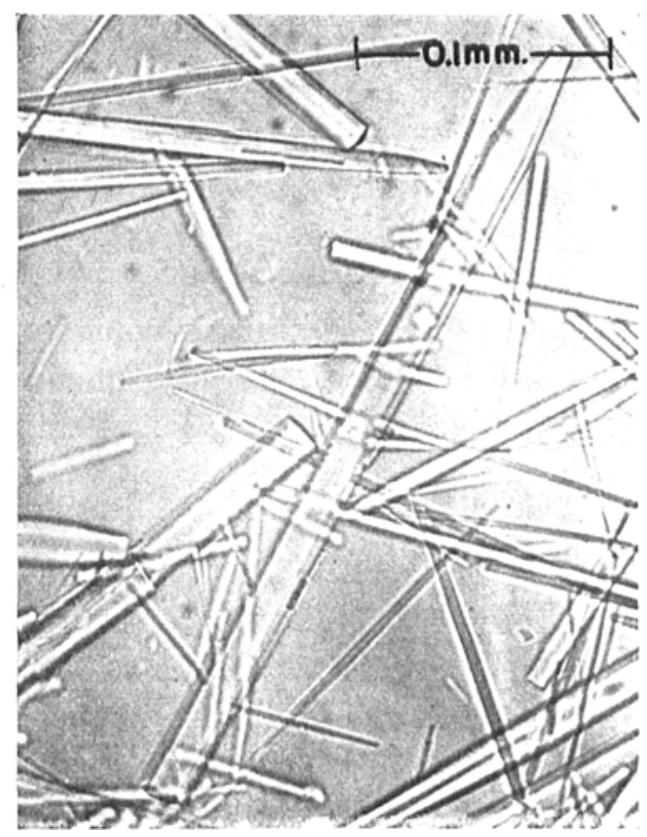

(1)

Fig. 2 a-d. Crystals of human and bovine serum albumin. From E. J. Cons, W. L. Hughes jr., and J. H. Wsare, J. amer. chem. Soc. 69, $1753(10+7)$.

Both human and bovine serum albumins have been crystallized from ethanol-water mixtures at $-5^{\circ}$ (COHN, Hughes, and Weare (36) ]. Crystallization can be carried out either at low ethanol concentration (below $25 \%$ ) 
and low ionic strength, or at higher ethanol concentration (up to $40 \%$ ) and higher ionic strength. It was found particularly in the case of human albu min that the addition of small amounts of long chain aliphatic alcohols such as decanol, or of certain other organic substances, was necessary to make possible reproduceable crystallization. All the aliphatic alcohols containing 5 or more carbon atoms proved effective. So also did $n$-amyl chloride. The effective concentrations for crystallization varied between 0.01 and $1 \%$. Benzene and toluene were also found to aid in crystallization; so also did chloroform and ethylene dichloride at concentrations near $1 \%$. The physical properties of the crystallized albumins of human and bovine plasma were reported in detail by COHN, Hughes, and WeARE.

An entirely new method of crystallization of human serum albumin has been developed recently by Huches (84). This involved the addition of mercuric chloride - approximately one-third mol per mol of albumin - to a $15 \%$ solution of Fraction $V$, or of human serum albumin previously crystallized with decanol. Most of the albumin separated within a few days on standing at $-5^{0}, \mathrm{p}_{\mathrm{H}} 5.2$, and ionic strength 0.02 . Only about two-thirds of the total albumin could be crystallized in this fashion; the remaining albumin in the mother liquor was not crystallizable on being readjusted to the same conditions used for the crystallization from the total albumin solution. The crystals were found to contain one-half mol of mercury per mol of protein, suggesting that two albumin molecules are linked through one atom of mercury in the solid state. The crystals were sparingly soluble in water but dissolved readily in $0.02 \mathrm{M}$ sodium chloride and could be recrystallized by the addition of ethanol. The mercury could be removed by dialysis in the presence of $0.001 M$ cysteine. Ultracentrifuge studies of solutions freshly prepared from the crystals revealed two components, one with sedimentation constant $4.6 \mathrm{~S}$, typical of ordinary serum albumin, and the other with a sedimentation constant of approximately $6.5 \$$. The latter appeared to be a dimer, presumably composed of two albumin molecules linked through a mercury atom. The dimer completely disappeared on addition of cysteine, BAL, or an excess of mercuric chloride ( $1 \mathrm{~mol}$ per mol albumin or more). This use of mercury for the crystallization of serum albumin recalls its use by WARLURG and his associates in the crystallization of enolase and other enzymes (152). Photographs of human and bovine serum albumins crystallized under various conditions are given in Figure $2 \mathrm{a}-\mathrm{d}$.

\section{The Lipoproteins of Plasma.}

The presence of lipids and steroids in close association with certain plasma protein fractions has often been observed. An excellent brief account of some of this earlier work has already been given by CHARGAFF (23). MACHEBOEUF (97) in 1929 obtained a water-soluble (or salt-soluble) lipoprotein 
from horse serum by precipitating most of the globulin with half-saturated $\left(\mathrm{NH}_{4}\right)_{2} \mathrm{SO}_{4}$, and acidifying the filtrate to $\mathrm{P}_{H} 3.8$ The precipitate so separated was redissolved at $p_{\mathrm{H}} 7$, and repeatedly reprecipitated at $\mathrm{p}_{\mathrm{H}} 3.8$. The final product contained $17.9 \%$ cholesterol esters and $22.7 \%$ phospholipids, and was soluble in water to a concentration of $50 \mathrm{~g} / 1$. [See also (98).]

Blix, Tiselius, and Svensson (12) studied the lipid content of electrophoretically separated albumin and $\alpha-, \beta$-, and $\gamma$-globulins from human serum. The lipid was associated chiefly with the $\alpha$ - and $\beta$-globulin fractions ${ }^{1}$.

ADAIR and ADAIR (1) obtained a globulin fraction of low density from human Serum, by precipitation between 0.5 and 0.6 saturation with $\left(\mathrm{NH}_{4}\right)_{2} \mathrm{SO}_{4}$. They found $8.5 \%$ phospholipid, $16,5 \%$ cholesterol, and $20.4 \%$ of fatty acids in the reprecipitated protein. The molecular weight from osmotic pressure was 370,000 .

In this laboratory, two sharply distinct lipoproteins, both euglobulins and both highly soluble in aqueous saline solutions, have been obtained by the low temperature - low salt - ethanol fractionation: an $\alpha_{1}$-lipoprotein from Fraction IV-1, and a $\beta_{1}$-lipoprotein from Fraction III-0. The former has a molecular weight of the order of 200,000 , and the latter of the order of 1,000,000 [ONCLIy, Scatchard, and Brown, (117)]. Some of the properties of these lipoproteins are given in Table IV, together with those reported by other investigators. It should be noted that the $\beta_{1}$-lipoprotein

Table IV. Lipoproteins Isolated from Plasma.

\begin{tabular}{|c|c|c|c|c|c|}
\hline Investigators & $\left|\begin{array}{c}\text { Principal } \\
\text { Electro- } \\
\text { phoretic } \\
\text { Component }\end{array}\right|$ & $\begin{array}{c}\text { Sedimen- } \\
\text { tation } \\
\text { Constant } \\
\mathrm{s}_{\mathbf{2 0}}, \mathrm{W}\end{array}$ & $\begin{array}{l}\text { Per Cent } \\
\text { Nitrogen }\end{array}$ & $\begin{array}{r}\text { g. per } \\
\text { Dry I } \\
\text { Cholesterol }\end{array}$ & $\begin{array}{l}100 \mathrm{~g} . \\
\text { Protein } \\
\text { Total Lipid }\end{array}$ \\
\hline 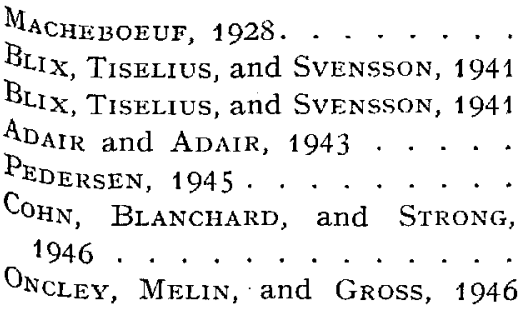 & $\begin{array}{c}\left(\alpha_{1}\right) \\
\alpha \\
\beta \\
\ldots \\
\ldots \\
\alpha_{1} \\
\beta_{1}\end{array}$ & $\begin{array}{l}4.1 \\
\ldots \\
\ldots \\
\ldots \\
6 . \\
5 . \\
6 .\end{array}$ & $\begin{array}{c}8.0 \\
\ldots \\
\ldots \\
6.4 \\
\ldots \\
10 . \\
4 .\end{array}$ & $\begin{array}{c}18 . \\
4.4 \\
9 . \\
16.5 \\
\ldots \\
16 . \\
35 .\end{array}$ & $\begin{array}{l}50 \\
\ldots \\
\cdots \\
46 \\
\ldots \\
35 \\
75\end{array}$ \\
\hline
\end{tabular}

(involved in the $\mathrm{X}$-protein phenomenon described by Pedersen (119)] although containing $75 \%$ lipid, is soluble to the extent of $10 \%$ or more in dilute aqueous salt solutions. It can be repeatedly reprecipitated at low ionic strength, and redissolved by addition of salt, without denaturation. Both it and the $\alpha_{1}$-lipoprotein, however, are denatured, with release of lipid, on exposure to high alcohol concentrations, or on freezing to temperatures below $-25^{\circ}$, [see McFarLane (96)].

1 Blix, Tiserius, and ${ }^{-S}$ Svensson reported also appreciable amounts of cholesterol and phospholipid in their albumin and $\alpha$-globulin fractions. This probably indicates that these fractions were impure, since CoHN, STRONG, et al. (39) report $<0.06 \%$ cholesterol in chemically purified $\gamma$-globulin, and $<0.04 \%$ in albumin. 
The carotenoids of plasma are found, for the most part, in the $\beta_{1}$-lipoprotein ${ }^{1}$, although some carotenoid is also present in the $\alpha_{1}$-lipoprotein. The latter contains most of the bile pigments of plasma. The steroids of plasma, including the estrogens, are found in the $\beta_{1}$-lipoprotein (124). This protein is also remarkable in being apparently characteristic only of human plasma, in all the species yet investigated. Pedersen (119) says that it was not

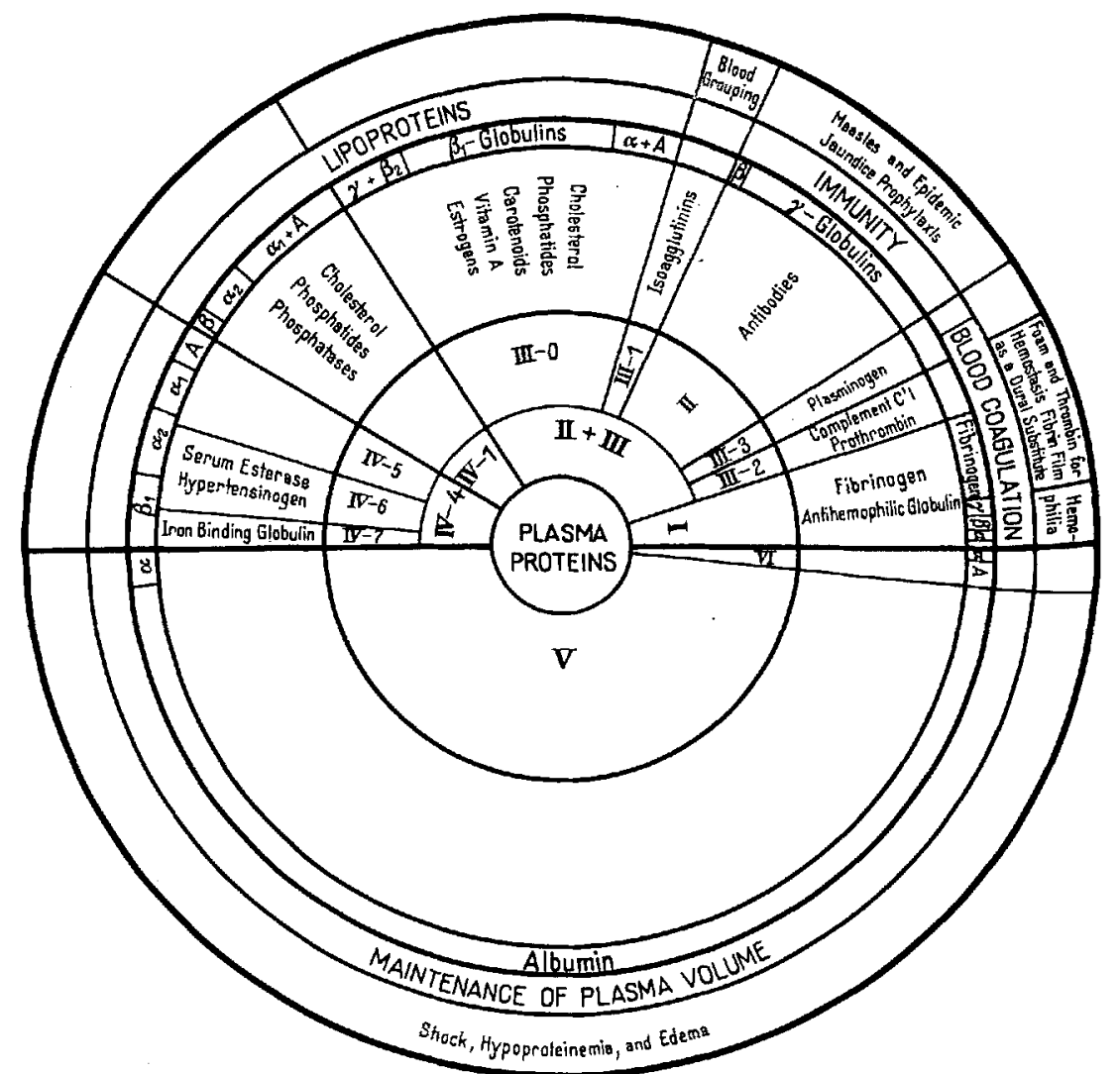

Fig. 3. Plasma Proteins. Their Natural Functions and Clinical Uses and Separation into Fractions.

detected in any other plasma during his ultracentrifugal studies, and fractionation studies in this laboratory and in the Armour Laboratories on several animal plasmas are entirely in accord with his statement.

Recently a detailed study of the $\beta$-lipoprotein of human plasma has been reported by ONCLEY, GURD and MeIrin (114a); and a brief general summary of the properties of plasma lipoproteins has been presented by ONCLEY, GuRD, EDSALl and CoHN (114b).

The distribution of human plasma proteins into fractions and subfractions is diagrammatically represented in Fig. 3 ifor an earlier version, see $\mathrm{COH}^{\mathrm{N}}$ $(28,30)$ or ONCLEY et al., (115)].

\footnotetext{
${ }^{1}$ Unpublished work of J. W. MEHL in the Harvard Plasma Fractionation Laboratory. See Oncley, Mrin, Richert, Cameron, and Gross (116).
} 


\section{Ether Fractionation of Human Plasma.}

In England, during the war, precipitation with ether at low temperature was employed as a method of separation of fibrinogen and prothrombin from plasma [KEKWICK, MACKAY, and RECORD (86)]. Ether is soluble in plasma, at $0^{0}$ to $-0.5^{\circ} \mathrm{C}$, to 11 vols. per $100 \mathrm{cc}$, and on addition of ether to this concentration $90 \%$ of the total plasma fibrinogen is precipitated. The precipitate is only about $40 \%$ fibrinogen, but can be further purified by reprecipitation with ether. The plasma supernatant, after precipitation of fibrinogen, is adjusted to $p_{\mathrm{H}}$ 5.3-5.4 with citric acid. A yellow precipitate is formed, containing prothrombin, which is then converted to thrombin. Thus the starting materials for fibrin foam, fibrin film, and other products related to fibrinogen are obtained. Ether is not sufficiently soluble in plasma to permit further fractionation; instead, the residual liquid, after prothrombin removal, is frozen with ether below -250 [McFARLANE (96)], thus largely breaking the bonds between protein and lipid in the lipoproteins, the lipids are extracted, and the remaining clear fluid can be used for clinical injection in shock and other conditions. Presumably, if used on a large scale, this method must be employed with special precautions, on account of the inflammability of ether.

Table V. Protein Components of Normal Human Plasma Characterized by Physical Chemical Methods [ONCLEY, SCATCHARD and BROWN (117)].

\begin{tabular}{|c|c|c|c|c|c|c|c|c|c|}
\hline \multirow[t]{2}{*}{$\begin{array}{l}\text { Uectrophoretic } \\
\text { Component }\end{array}$} & \multirow[t]{2}{*}{ Fraction } & \multirow{2}{*}{ 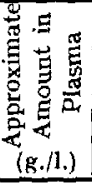 } & \multirow{2}{*}{ 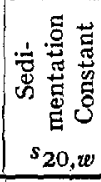 } & \multirow{2}{*}{ 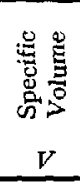 } & \multirow{2}{*}{ 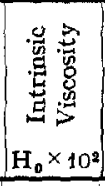 } & \multirow{2}{*}{ 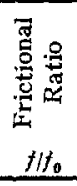 } & \multirow{2}{*}{$\begin{array}{c}\begin{array}{c}\text { Molecular } \\
\text { Weight }\end{array} \\
M \\
\end{array}$} & \multicolumn{2}{|c|}{$\begin{array}{l}\text { Approximate } \\
\text { Dimensions } \\
\text { (Angströms) }\end{array}$} \\
\hline & & & & & & & & Length & Diameter \\
\hline & $\mathrm{V}$ & 32 & 4.6 & 0.733 & 4.2 & 1.28 & 69,000 & 150 & 38 \\
\hline bulin & $I V-1$ & $2^{1}$ & 5.0 & .841 & 6.6 & 1.38 & 200,000 & 300 & 50 \\
\hline bulin & IV -6 & 1 & 9. & .693 & 9.2 & 1.58 & $(300,000)$ & $\ldots$ & $\ldots$ \\
\hline obulin & IV -7 & 2 & 5.5 & .725 & 5.5 & 1.37 & 90,000 & 190 & 37 \\
\hline Obulin & $\mathrm{III} \longrightarrow 0, \mathrm{III}-2$ & 2 & 7. & .74 & $\cdots$ & $\ldots$ & $(150,000)$ & $\ldots$ & . \\
\hline lobulin & III -0 & 1 & 20. & .74 & .. & $\cdots$ & $500,000-1,000,000$ & $\cdots$ & 185 \\
\hline obulin & $I I I-0$ & $2^{1}$ & $2.9^{2}$ & .950 & 4.1 & $1.7^{2}$ & $1,300,000$ & 185 & $\ldots$ \\
\hline bulin & III -1 & 2 & 7. & $\cdots$ & $\cdots$ & $\cdots$ & $(150,000)$ & $\cdots$ & $\cdots$ \\
\hline & II & 5 & 7.2 & .739 & 6. & 1.38 & 156,000 & 235 & 44 \\
\hline & II & 1 & 10. & .739 & $\cdots$ & $\cdots$ & $(300,000)$ & $\ldots$ & .. \\
\hline ugen & $I-2$ & 2 & 9. & $\ldots$ & 25. & 1.98 & 400,000 & 700 & 38 \\
\hline
\end{tabular}

1 These two globulins are lipoproteins containing $35 \%$ lipid for the $\alpha_{1}$-globulin and $75 \%$ lipid for the $\beta_{1}$-globulin. The other components contain little or no lipid.

2 This is the sedimentation constant obtained in $0.5 M$ sodium chloride solution, then corrected in the usual manner. The $f i f_{0}$ value given here is the value for sedimentation, correcting for the partial specific volume of the hydrated protein $(0.97)$, using the equation of KRAEMER (equation 124, p. 65, reference 145). A solvation of $0.6 \mathrm{~g}$. of water per g. of protein was used for this calculation, and the molecule was assumed \$pherical. 


\section{ro. Size and Shape of Molecules in Plasma Fractions.}

Studies of sedimentation constant, viscosity, osmotic pressure, and partial specific volume of plasma fractions have permitted estimation of molecular

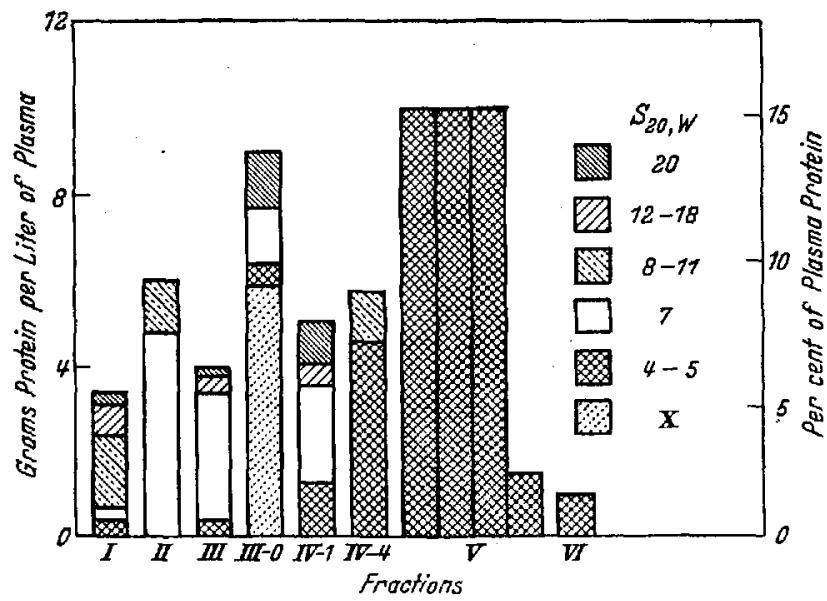

Fig, 4. Distribution of ultracentrifugal components in fractions of buman plasma. Three bars, and a portion of a fourth, are necessary to represent the composition of Fraction $V$ (albumin), which makes up 48 per cent by weight of the total human plasma protein. From ONCLEY, Scatchard and Brown (117).

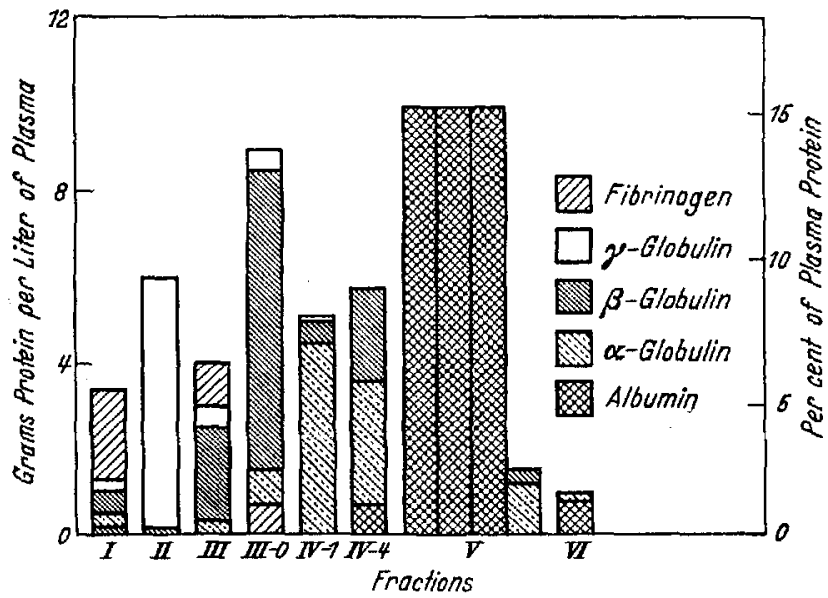

Fig. 5. Distribution of electrophoretic components in fractions of human plasma, arranged on the same plan as Fig. 4. From ONCLEY, SCATCIIARD and Brown (117). weights and axial ratios for many of the components involved [ONCLEY, SCATCHARD, and BROWN (117)]. The results are summarized in Table $\mathrm{V}$, and the ultracentrifugal data are also presented in Fig. 4. The height of each bar in the figure indicates the weight of that fraction obtained during fractionation. For Fraction $\mathrm{V}$ several bars are placed side by side, and the heights should be added together, this fraction representing $48 \%$ of $\mathrm{hu}^{-}$ man plasma protein by weight. In Fig. 5 a similar diagram is shown for the electrophoretic components from the various fractions. It is immediately apparent that there is no simple correspondence between the ultracentrifugal and the electrophoretic components. At least four distinct $\beta_{1}$-globulins have been identified, and it seems almost certain that other quite distinct $\alpha$ - and $\beta$-globulin components are still to be identified. The shapes of the molecules vary from that of the $\beta_{1}$-lipoprotein, which is very large and practically spherical, to the long thin molecule of fibrinogen, $700 \AA$ long and about one-twentieth as wide.

\section{I. Amino Acid Analysis of Plasma Fractions.}

Accurate data on the amino acid analysis of plasma fractions are now available from the work of BRAND and his co-workers $(16,18)$, who have 
employed chiefly colorimetric and microbiological procedures, while SHEmin (135) has determined the content of several amino acids in human and bovine serum albumin by the isotope dilution method. When BRANDs determinations were checked against those obtained by isotope dilution, excellent agreement was obtained. The data, given as per cent amino acid in the hydrolyzate from $100 \mathrm{~g}$. protein, are given in Table VI; and for human and bovine serum albumin, and human $\gamma$-globulin, they are given as residues per mol in Table VII

Table VI. Amino Acid Composition of Human Plasma Proteins. (gm. per 100 gm. Protein.)

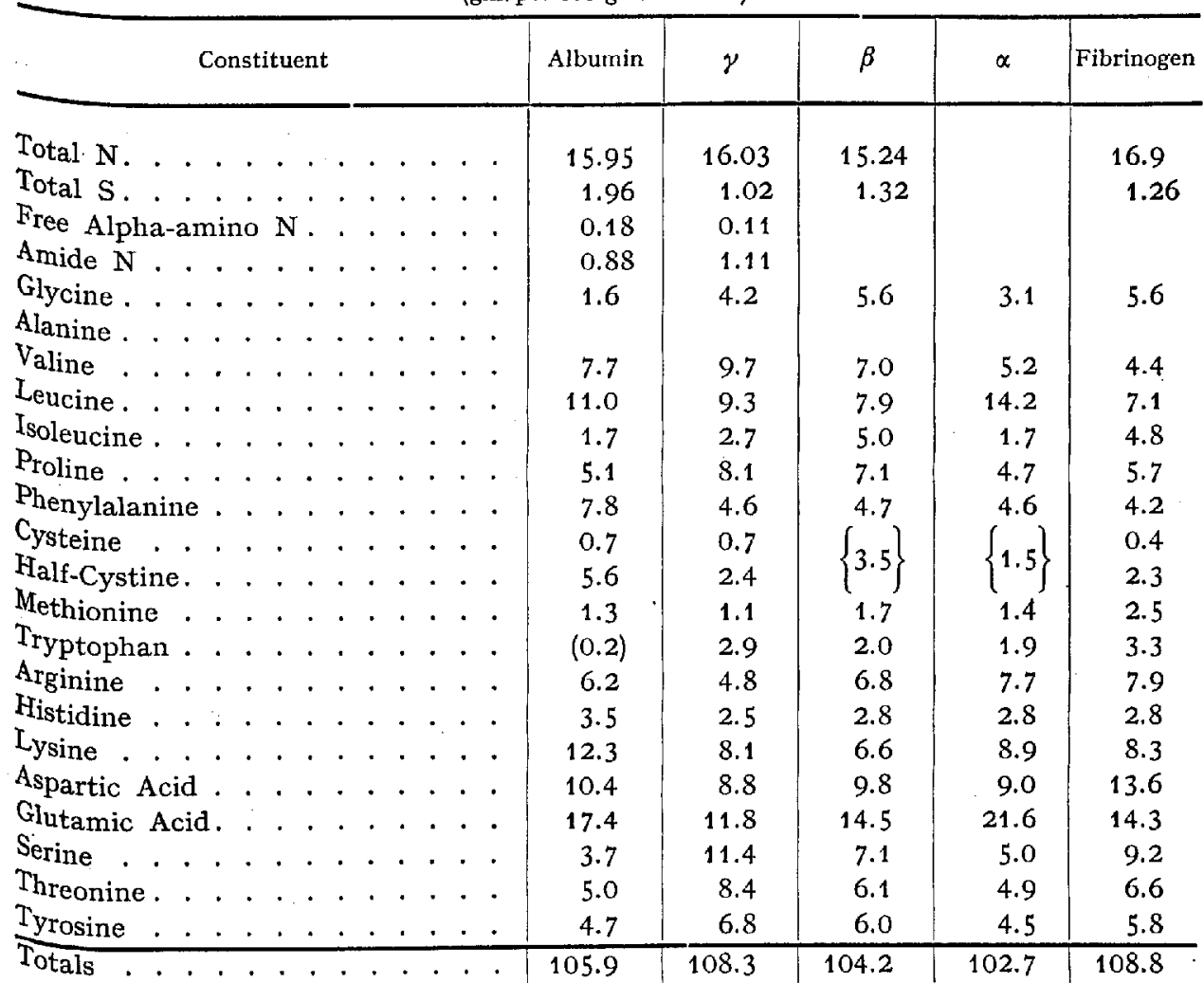

Albumin (V): No. 42. $-\gamma$-Globulin (II-1): No. 36. - $\beta$-Globulin (III-22 $\beta$-): No. L421. Alb. $=1 \%, \gamma-=1 \%, \alpha-=7 \%, \beta-=82 \%, \beta_{2^{-}}=9 \%, A s h=8.13 \%$, values on ash free basis. $-\alpha$-Globulin (IV-1): No. Run 146. $\alpha-=94 \%, \beta-=6 \%$, lipids $=35.2 \%$. Values on lipid free basis. - Fibrinogen (I): No. 81 RI, $87 \%$ clottable. - Data from Brand, Kassel.t and Saidel (18); Brand (16); Shemin (135).

It will be noted that human and bovine serum albumin, although strikingly similar in composition in most respects, differ significantly in their content of methionine, tryptophan, isoleucine, and certain other amino acids. The very high content of hydroxyamino acids in $\gamma$-globulin, and the still high but somewhat lower content of these acids in fibrinogen, are notable. Nutritional studies with rats $(21,78)$ have shown that fibrinogen is the most complete of these proteins, as a component of the diet. $\gamma$-Globulin is nearly as 
good, while human albumin is deficient in tryptophan and isoleucine. When supplemented with these two amino acids, albumin gives good growth (77).

Recently STEIN and Moore (136) [see also Moore and Stein (108)] have developed a comprehensive chromatographic technique for analysis of protein hydrolyzates, employing separation on a column of potato starch and analyzing the effluent by a photometric ninhydrin method. They have studied bovine serum albumin among other proteins by this technique. Their findingsare in general in good accord with those of BRAND. However, the discrepancies

Table VII. Amino Acid Content of Human and Bovine Serum Albumin and Human $\gamma$-Globulin Expressed as Residues Per Molecule of Protein.

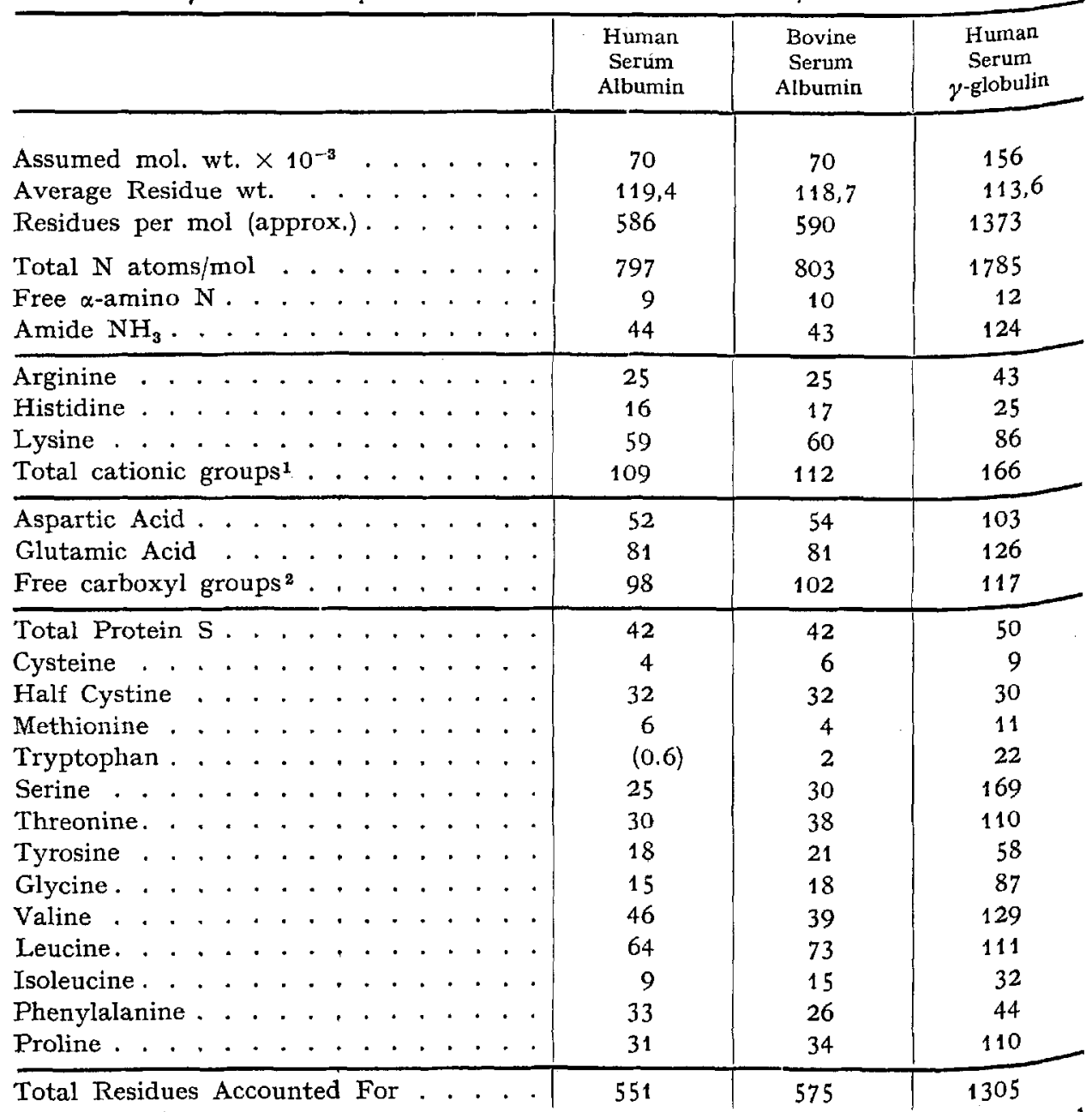

1 Total cationic groups are taken as the sum of the arginine, histidine, lysine, and $\boldsymbol{\alpha}$-amino residues.

2 Free carboxyl groups are taken as the sum of the total aspartic andglutamic acid plus free $\alpha$-carboxyl (assumed equal to free $\alpha$-amino) minus the amide nitrogen groups. - Data for the alanine content of these proteins are not yet available. Data from Brand, Kassell, and Saidel. (18) and from Brand (16). 
in several cases are beyond the assumed limits of probable error. For isoleucine they report $2.61 \%$ as compared with BRANDs figure of 2.9 , and for valine 5.92 as against BrANDs 6.5. On the whole, however, the results obtained by this entirely independent method of analysis are in reasonably encouraging agreement with those found by BRAND and his associates. [For a later report, see STEIN and MOORE (136a).]

\section{I2. Conclusions.}

The methods of separation here described for blood plasma are obviously not restricted to any particular tissue, and the field for their application appears to be practically unlimited. Each new tissue studied represents a new problem; a system of fractionation using organic solvents at low temperatures must be worked out afresh in each case. Even for human blood plasma, the system of fractionation described in this review is certainly not the only one conceivable, and probably not the best. Further studies on an improved method of fractionation are now in progress under the direction of E. J. CoHN, but the results are not yet ready for publication ${ }^{1}$. Certainly the system employed for human plasma is not necessarily the best for plasma of any other species. Marked species differences have already become apparent, even on the basis of the limited knowledge now available. Further progress will require constant experimentation. On proceeding from blood plasma to the fractionation of other tissues, new and complex problems arise. Most tissues contain a variety of active enzymes which can rapidly alter or inactivate many of the protein components and change them from the state in which they exist in the living tissues. In order to take account of these difficulties, it may be desirable to explore ranges for conditions of fractionation much wider than those employed with human plasma, decreasing the temperature still further and perhaps increasing the concentration of the organic solvent under some conditions. The possible combinations of conditions under which separation of proteins may take place are so numerous that they are almost infinite. General theoretical considerations regarding relation of solubility to structure furnish a very rough and approximate guide, but actual fractionation procedures on a tissue containing a great number of components are still, of necessity, largely empirical. Several years of trial on the part of a large group working under high pressure during the war Were required before certain protein components of plasma were separated in undenatured form. Other components have even yet not been separated in adequate yield or in unaltered form. However, these methods more than any others have furnished a basis for the comprehensive fractionation of all, or at least many, of the protein components of a given tissue, in contrast to most earlier methods which were concentrated on the separation of a

1 See Appendix, p. 352. 
single component. With further experience we may hope that a clearer pattern of underlying principles will emerge and that more systematic approach will be possible in considering the choice of conditions for the fractionation of other tissues not as yet investigated.

\section{Appendix (added February 1950).}

Recently important developments have occurred in the methods of collecting blood and separating the formed elements - erythrocytes, leucocytes and platelets - from the plasma, with the aim of making all these constituents available for study and clinical trial in a state as nearly native as possible. Much of the work in this field is briefly presented in a recent monograph ${ }^{1}$, containing reports by more than a hundred different workers. Notable new developments include the use of vessels coated with silicone, or made of suitable inert plastics, and of plastic tubing, so that the blood does not come into contact with glass or rubber; and the taking of the blood into human tibrinogen (Fraction I) solutions, so that the red cells settle rapidly and without being injured, under the influence of gravity, without centrifuging. This also permits separation of most of the white cells in a separate layer, if necessary with gentle centrifuging. The many other contributions discussed in this monograph cannot be mentioned here. Further active developments are now proceeding.

The major outlines of a new system of plasma fractionation have been presented by COHN, GURD, SURGENOR et al (35a). The chief differences from the methods described in the preceding pages of the present review are as follows:

1. Special efforts are made to obtain plasma very rapidly, within a few hours after the blood has been taken, with all due precautions to minimize alteration of blood components during the procedure.

2. Nearly all plasma proteins are precipitated, at low temperature in the presence of ethanol, at or near the very beginning of the process.' Subsequent steps generally involve fractional extraction of one or more components from a precipitate, rather than fractional precipitation from a solution. Since proteins are generally more stable in the solid state than in solution, the new procedure should favor the preservation of the more labile components of plasma.

3. Although the presence of ethanol in the system is essential to the process, the ethanol concentration remains nearly constant during the successive steps in fractionation, and is never higher than $0.066 \mathrm{~mol}$ fraction (19 vol. per cent). The $\mathrm{p}_{\mathrm{H}}$ also is never more acid than 5.5 at any step in the process.

4. Protein interactions, resulting in mutual precipitation of components of opposite charge under conditions where either component would be soluble alone, are deliberately utilized in some of the separations. Thus the $\gamma$-globulins and the $\beta$-lipoproteins are precipitated by such interaction in the first step of the process.

1 The Preservation of the Formed Elements and of the Proteins of the Blood (Proceedings of a Conference Held at Harvard Medical School, Boston, Massachusetts, January $6,7,8,1949$ ), Published by the American National Red Cross, Washington, D. $C$. 
5. This first step involves adjusting the plasma to $\mathrm{p}_{\mathrm{H}} 5.8$, with there or four volumes of added reagent, so that the ionic strength is near 0.04 , ethanol $0.066 \mathrm{~mol}$ fraction, and temperature $-5^{\circ} \mathrm{C}$. Under these conditions, the $\gamma$-globulins, the $\beta$-lipoprotein, the isoagglutinins, and virtually all the components concerned with blood coagulation, are precipitated. Serum albumin, $\alpha_{1}$-lipoprotein, metal combining $\beta_{1}$-globulin, and $\alpha_{2}$-glycoproteins remain in solution together with small amounts of some other proteins referred to below.

6. All the major protein components in this solution are precipitated by addition of zinc acetate $(0.02 \mathrm{~m})$, maintaining the ethanol at $0.066 \mathrm{~mol}$ fraction and $\mathrm{p}_{H}$ at 5.8. Most of what protein still remains is carried down by adjustment of $\mathrm{p}_{\mathrm{H}}$ to 7.5 , when a zinc hydroxide precipitate forms and removes the proteins with it. On readjusting the precipitate to $\mathrm{p}_{\mathrm{H}} 5.8$ the zinc is brought into solution at a much higher concentration (near $0.5 \mathrm{~m}$ ); most of the major components not originally precipitated at $\mathrm{p}_{\mathrm{H}} 5.8$ remain in the precipitate now. What goes into solution includes a number of small molecules not separated in earlier fractionation procedures. One of the largest is an $\alpha$-glycoprotein of relatively low molecular weight, isoelectric near $\mathrm{P}_{\mathbf{H}} 3$, which is currently being investigated by K. Schum in this laboratory.

7. The first precipitate, described in paragraph 5 above, can be treated to extract the $\gamma$-globulins by adding a solution containing glycine $(0.6 \mathrm{~m})$ at $\mathrm{P}_{\mathrm{H}} 5.5$ and very low ionic strength, and at ethanol $0.051 \mathrm{~mol}$ fraction (15 per cent by volume). The glycine dissociates the complex between $\gamma$-globulin and $\beta$-lipoprotein. The further steps employed in separation of the other compohents will not be discussed here.

8. Utilizing a procedure developed by Dr. JoHN G. GIBson, 2nd, the blood may be rendered calcium free by passage through an ion exchange resin ${ }^{1}$. It is then unnecessary to add citrate to the plasma to prevent clotting. Prothrombin may then be adsorbed from the plasma on to barium sulfate, following a procedure described by ALE XANDER and LANDWEHR (2a), and then eluted from the barium sulfate with sodium citrate solution ${ }^{2}$. Subsequent steps in fractionation of the prothrombin-free plasma may then be carried out as described above; or as a preliminary step, following the $\mathrm{BaSO}_{4}$ treatment, the fibrinogen may first be removed by precipitation at very low ethanol concentration, before the separation of the other components is begun.

This discussion of new developments is necessarily preliminary and very incomplete. New developments are now proceeding rapidly, and the search for more specific and selective reagents for dissolving certain proteins is being actively carried on. Some of the bivalent and trivalent cations of heavy metals promise to play a role of particular importance in these studies.

\footnotetext{
1 Dowex-50 (Dow Chemical Co.), an alkyl sulfonate resin. It is used on the sodium cycle.

2 It is thus apparent that the adsorption with $\mathrm{BaSO}_{4}$ can be successful only when citrate free plasma is used in the first place. 